\title{
Ortaokul Öğrencilerinin Okul Doyumu İle Yaşam Doyumları Arasındaki İlişki: Umudun Aracı Rolünün İncelenmesi ${ }^{1}$
}

\author{
Faruk Caner $\mathrm{YAM}^{2}$ ve Hatice KUMCA $\breve{G} Z^{3}$
}

$\ddot{\mathrm{O} z}$

$\mathrm{Bu}$ araştırmada ortaokul öğrencilerinin okul doyumu ve yaşam doyumu arasındaki ilişkide umudun aracı rolünün incelenmesi amaçlanmıştır. Araştırmada ilişkisel tarama modeli kullanılııştır. Araştırmanın çalışma grubu, 2018-2019 eğitim öğretim yılında Orta Karadeniz Bölgesi’ndeki bulunan bir ildeki üç farklı ortaokulda öğrenim gören 105 kız ve 106 erkek öğrencinden oluşturmaktadır. Çalışmanın verilerinin toplanmasında Çocuklar İçin Kapsamlı Okul Doyumu Ölçeği, Çocuklar İçin Yaşam Doyumu Ölçeği ve Çocuklar İçin Umut Ölçeği kullanılmıştır. Araştırmada bağımsız örneklem t-testi, tek yönlü varyans analizi, yapısal eşitlik modellemesi ve doğrulaycı faktör analizi kullanılmıştır. Araştırmanın bulgularına göre ortaokul öğrencilerinin okul doyumu düzeyleri cinsiyete göre erkek öğrencilerin lehine anlamlı olarak farklılaşmıştır. Diğer açıdan öğrencilerin umut ve yaşam doyumu düzeyleri, cinsiyet değişkenine göre olarak anlamlı bir şekilde farklılaşmamıştır. Çalışmada ortaokul öğrencilerinin umut ve yaşam doyumu puanları sınıf düzeyi değişkenine göre istatistiksel olarak anlamlı bir şekilde farklılaşırken, okul doyumu puanları sınıf düzeyi değişkenine göre anlamlı olarak farklılaşmamıştır. Yapılan yapısal eşitlik modellemesinde ortaokul öğrencilerinin okul doyumu ve yaşam doyumu arasındaki ilişkide umudun kısmi aracılık rolüne sahip olduğu belirlenmiştir. Elde edilen bu sonucun ortaokul öğrencilerin yaşam doyumlarının artırılması çalışmalarında kullanılabileceği düşünülmektedir. Ayrıca araştırmada elde edilen bulguların ileride bu alanda yapılacak olan araştırmalar için bir temel oluşturacağı ifade edilebilir.

Anahtar Kelimeler: Aracılık etkisi, Ortaokul öğrencileri, Okul doyumu, Umut, Yaşam doyumu

\section{The Relationship Between Secondary School Students' School Satisfaction and Life Satisfaction: Examining the Mediating Role of Hope}

\section{Abstract}

In this study, it is aimed to examine the mediating role of hope in the relationship between secondary school students' school satisfaction and life satisfaction. The study group of the research consists of 105 female and 106 male students studying at three different secondary schools in a city in the Middle Black Sea Region in the 2018-2019 academic year. Comprehensive School Satisfaction Scale for Children, Life Satisfaction Scale for Children and Life Satisfaction Scale for Children were used to collect the data of the study. Independent sample t-test, one way variance analysis, structural equation modeling and confirmatory factor analysis were used in the study. According to the findings of the study, school satisfaction levels of secondary school students differed significantly in favor of male students according to gender. Hope and life satisfaction levels of students did not differ significantly according to gender. The hope and life satisfaction scores of secondary school students differed significantly according to the grade level variable. In the structural equation modeling, it was determined that hope has a partial mediating role in the relationship between secondary school students' school satisfaction and life satisfaction. It is thought that this result can be used in studies to increase the life satisfaction of secondary school students. In addition, it can be stated that the findings obtained in the research will form a basis for future research in this field.

Key Words: Hope, Mediating effect, Secondary school student, School satisfaction, Life satisfaction

\section{Atıf İçin / Please Cite As:}

Yam, F. C. ve Kumcağız, H. (2020). Ortaokul öğrencilerinin okul doyumu ile yaşam doyumları arasındaki ilişki: Umudun arac1 rolünün incelenmesi. Manas Sosyal Arasstrmalar Dergisi, 9(4), 2113-2130.

Geliş Tarihi / Received Date: 15.04.2020

Kabul Tarihi / Accepted Date: 07.09.2020

\footnotetext{
${ }^{1}$ Bu çalışma 26-28 Ekim tarihinde Ondokuz Mayıs Üniversitesi bünyesinde düzenlenen Uluslararası 100. Yıl Eğitim Sempozyumu'nda sunulan sözlü bildirinin genişletilmiş halidir.

2 Öğr. Gör. - Gaziosmapaşa Üniversitesi, Adalet Meslek Yüksekokulu, farukcaner.yam@gop.edu.tr ORCID:0000-0001-8392-9576.

${ }^{3}$ Doç. Dr. - Ondokuz Mayıs Üniversitesi, Eğitim Fakültesi, haticek@omu.edu.tr

ORCID: 0000-0002-0165-3535
} 


\section{Giriş}

Okullar, öğrencilere bilişsel, duyuşsal ve davranışsal açıdan eğitim ve öğretim yaşantıları sunan kurumladır (Çengel, Totan ve Çöğmen, 2017, s. 182; Yıldız ve Kutlu, 2015, s. 335). Bireyin okulda edinmiş olduğu bilgi ve beceriler, arkadaşları ve öğretmenleriyle kurduğu ilişkinin kalitesi çocuğun tüm yaşam alanları üzerinde önemli rol oynamaktadır (Karababa, Oral ve Dilmaç, 2018, s. 168). Kurulan bu ilişkinin kaliteli olması, iyi arkadaşılılar geliştirilmesi ve okul ile ilgili yaşantılarının olumlu olması, çocuğun okula karşı olumlu duygular geliştirmesine katkı sağlamaktadır (Yıldız ve Kutlu, 2015, s. 337). Bu süreçte okul içi ilişkilerden ve okuldaki olumlu ve olumsuz yaşantılardan etkilenen bir kavram olan okul doyumu karşımıza çıkmaktadır (Huebner ve Alderman, 1993, s. 73). Okul doyumu, çocuğun okulun tüm yaşantılardan zevk alabilme ve okulda bulunduğu süre içerisinde kendisini iyi hissetme düzeyi olarak tanımlanmaktadır (Huebner, 1994, s. 151). Ayrıca okul doyumu, öğrencilerin okulda geçirdikleri deneyimlerine ilişkin bilişsel ve duygusal değerlendirmelerini de içermektedir (Baker, Dilly, Aupperlee ve Patil, 2003, s. 208; Verkuyten ve Thijs, 2002, s. 210). Öğrencilerin okul doyumları üzerinde olumlu okul iklimi (King vd., 2006, s. 282; Suldo, Thalji-Raitano, Hasemeye, Gelleyve Hoy, 2013, s. 570), okuldaki sosyal destek (Baker, 1998), destekleyici öğretmen ve akran davranışlarının (Huebner ve Alderman, 1993, s. 79; Tian, Liu, Huang ve Huebner, 2013, s. 360) etkili olduğu bilinmektedir. Diğer taraftan okul doyumunun yüksek olması ögrencilerin okul başarıları, okula devam düzeyleri, psikolojik iyi oluşları ile okul içi davranışsal sorunların görülme sıklğg üzerinde etkisi bulunmaktadır (King, Huebner ve Suldo, 2006, s. 293; Telef, 2014, s. 488; Verkuyten ve Thijs, 2002, s. 225; Zullig vd., 2009, s. 140). Ayrica okul doyumu, genel yaşam doyumunun önemli bir boyutunu oluşturmaktadır (Tian, Chen ve Huanber, 2014, s. 368). Öğrencilerin okul temelli yaşantılardan doyum sağlaması, onların bütün yaşantıları üzerinde etkili olabilmektedir (Kalaycı ve Özdemir, 2013, s. 300). Çünkü okul çağı ergen ve çocukların özellikle okul yaşamlarına ilişkin bilişsel yargıları (okul iklimi, arkadaş ve öğretmen ilişkilerin vb. yaşantılara ait değerlendirmeleri) yetişkin bireylere kıyasla, yaşam doyumları içeresinde önemli bir yer tutmaktadır (Huebner, Laughlin, Ash ve Gilman, 1998, s. 127; Valera vd., 2017, s. 492). Çünkü yaşam doyumu bireyin tüm yaşam alanlarına ilişkin değerlendirmeleri barındırdığından dolayı, zamanının büyük bir bölümünü okullarda geçiren öğrencilerin okul doyum düzeylerinin yaşam doyumları üzerinde büyük etkisi olması beklenen bir durumdur (King vd., 2006, s. 293). Dolayısiyla okul doyumu yüksek olan öğrencilerin, genel yaşam doyum düzeylerinin de yüksek olacağı ifade edilmektedir (Karababa vd, 2018, s. 273; Lewis, Huebner, Malone ve Valois, 2011, s. 257).

Yaşam doyumu, bireyin tüm hayatı ile ilgili yapmış olduğu öznel değerlendirmeleri içeren bir kavramdır (Diener ve Lucas, 1999, s. 217). Diğer bir ifade ile yaşam doyumu, bireylerin aile, sosyal çevre, okul, iş ve sosyal lişkileri gibi yaşamındaki tüm alanlara yönelik bilişsel yargılarıdır (Diener ve Diener, 1995, s. 659; Appleton ve Song, 2008, s. 2330; Suldo, Riley ve Shaffer, 2006, s. 577). Başka bir ifade ile yaşam doyumu, bireyin beklentileri ile içinde bulunduğu koşulları kıyaslayarak elde ettiği memnuniyet düzeyidir (Myers ve Diener, 1995, s. 13). Yaşam doyumu bireylerin öznel iyi oluşlarını bir bileşeni oluşturmaktadır (Diener, 1984, s. 562). Öznel iyi oluş ise bireyin mutluluk alanı ile ilgili önemli bir psikolojik faktördür (Diener ve Lucas, 1999, s. 221). Bu nedenle bireylerin aile, okul, iş ve benzeri yaşam alanlarından elde edecekleri doyumlar, onların mutlulukları üzerinde oldukça etkili olmaktadır (Diener, 2000, s. 39). Yüksek yaşam doyuma sahip bireylerin mesleki ve fiziksel yeterliklerinin daha iyi olduğu (Lyubomirsky ve vd, 2005, s. 127), daha fazla olumlu sosyal ilişkiler geliştirdikleri (Lewis vd., 2011, s. 252) ve daha sağlıklı bireyler oldukları bilinmektedir (Diener ve Lucas, 1999, s. 215). Bireylerin hayatlarında bu denli önemli olan yaşam doyumu, ergenlerin hayatlarında da önemli bir yere sahiptir (Huebner, Suldo, Smith ve McKnight, 2004, s. 84). Okul çağındaki ergen ve çocukların arkadaş, okul, öğretmen gibi alanlardaki memnuniyet düzeyleri de yaşam doyumlarına büyük katkılar sağlamaktadır. Fakat ergenlerin yaşam doyumları ile ilgili yapılan araştırmaların, yetişkinler ile ilgili yapılan çalışmalardan oldukça az olduğu göze çarpmaktadır (Huebner vd., 2005, s. 19). Ergenelerle yapılan çalısmaların sayısı az olmasına rağmen yaşam doyumunun, ergenlerin tüm yaşam alanlarındaki uyum düzeyleri üzerinde etkili olan bir faktör olarak ifade edilmektedir (McKnight, Huebner ve Suldo, 2002, s. 681). Diğer açıdan ilk ergenlik dönemlerindeki bireylerin yaşam doyum düzeylerinin, çocukluk dönemlerine ve ergenliğin son dönemlerine göre daha düşük olduğunu gözlenmektedir (Chang, Chang, Stewart ve Au, 2003, s. 185; Ullman ve Tatar, 2001, s. 453). Bu duruma, ergenlerin içinde bulundukları gelişim döneminin getirmiş olduğu zorlukların neden olabileceği ifade edilmektedir (Leung ve Leung, 1992, s. 660). Ergenlik dönemindeki bireyler, diğer dönemlere kıyasla olumsuz duyguların daha sık ve yoğun hissetmekte ve kimlik kazanımı ile ilgili bazı sorunlar yaşayabilmektedir (Dew ve Huebner, 1994, s.191; Goldbeck, Schmitz, Besier, Herschbach ve Henrich, 2007, s. 973). Bundan dolayı alan yazında ergenlerin yaşam doyumlarının desteklemesi gerektiği 
ifade edilmektedir (Suldo ve Huebner 2004, s. 99). Bu bilgiyi destekleyen bir araştırmada, yaşam doyumu yüksek olan ergenlerin daha az depresyon yaşadıkları ve benlik saygılarının daha yüksek olduğu sonucuna ulaşılmıştır (Gilman ve Huebner, 2006, s. 315). Yani yaşam doyumunun, ergenleri stresli yaşam olaylarına karşı koruma görevi üstlendiği görülmektedir (Saha, Huebner, Hills, Malone, Valois, 2012, s. 247). Diğer taraftan alan yazında yapılan çalışmalarda yaşam doyumu yüksek öğrencilerin okula devam etme sıklıklarının yüksek olduğu ve okulla ilgili olumlu tutumlara sahip oldukları (Suldo ve Shaffer, 2008, s. 64), okul doyumlarının daha yüksek olduğu (McCabe, Bray, Kehle, Theodoreve Gelbar, 2011, s. 188), okula yönelik duygusal ve akademik uyumlarının daha iyi olduğu (Huebner, vd., 2004, s. 90; Tolan ve Larsen, 2014, s. 507) sonucuna ulaşılmışlardır. Kuramsal bilgiler ve yapılan araştırmaların bulguları ergenlerin okul doyumları ile yaşam doyumları arasında karşıllk olarak pozitif bir ilişkinin olduğu görülmektedir. Ancak, yaşam doyumunun teorik alt yapısı incelendiğinde okul doyumunun yaşam doyumunu bir bileşeni olarak açıklandığ1 görülmektedir (Diener, 2000, s. 38; Tian vd., 2014, s. 367). Bu nedenle mevcut araştırma kuramsal yapıya bağlı kalınarak sürdürülmüştür.

Umut, bireyin yaşamış olduğu dünyaya ilişkin duymuş olduğu güven ve içinde bulunduğu hayatın yaşamaya değer olarak görülmesi ve geleceğine olumlu bir bakış açısı taşıması olarak tanımlanmaktadır (Zournazi, 2004, s. 29; Teltey, 2010, s. 43). Diğer açıldan umut geleceğe dair olumlu beklentiler geliştirme ve ileriki yaşamına dair pozitif amaçlar belirlemeyi içeren bir kavramdır (Snyder, 2000, s. 15). Umut kavramı belirli bir hedefe ulaşma isteği ve çabasını içermektedir (Snyder ve Lopez, 2007, s. 329). Çünkü Snyder'e (2000) göre umut sadece bir duygu değildir, aynı zamanda bireyin bilişsel ve motivasyonel süreçlerinin etkileşimden oluşan bir yapıdır. Diğer bir ifade ile umut bireylerin ulaşılabilir hedefler belirleyip, bu hedeflere ulaşmak için yollar oluşturabilme kapasitesini de yansıtmaktadır (Snyder, Harris, Anderson, Holleran ve Irving, 1991, s. 579-581). Bireylerde umut düzeyinin yüksek olması yaşam kalitelerini, iş hayatlarını, eğitim hayatlarını ve akademik yılmazlıklarını, sınav başarılarını olumlu yönde etkilediği ifade edilmektedir (Snyder, Cheavens ve Sympson, 1997, s. 111, Snyder, 2005, s. 79; Tarhan ve Bacanlı, 2016, s. 573). Bundan dolayı umut kavramı, okul ortamında bulunan öğrencilerin geleceğe yönelik ulaşmak istedikleri akademik hedefler oluşturması ve bu yönde çaba göstermeleri açısından önemli bir faktördür (Snyder vd., 1991, s. 579). Umut düzeyi yüksek olan ve geleceğe yönelik umut besleyen ergenlerin okul başarısızlıklarında veya hayatlarında karşılaşabilecekleri olumsuzluklara karşı daha dayanıklı oldukları ifade edilmektedir (Kemer ve Atik, 2005, s. 909).Diğer bir ifade ile umutlu olmak bireyleri koymuş oldukları hedeflere ulaşmada onları tetikleyen bir faktör ve hayatlarındaki tüm alanlarda (okul, iş, sağlık, vb.) karşılaşabilecekleri olumsuzluklara karşı bir psikolojik kalkan görevi görmektedir (Carr, 2011, s.61; Snyder vd., 1997, s. 580; Snyder, 2002, s.271). Ergenlerin akademik başar1, okul faaliyetlerine katılım, okula, akranlarına ve öğretmenlerine karşı olumlu tutumlar geliştirmeleri umutlu ile pozitif ilişkili süreçlerdir (Curry, Snyder, Cook, Ruby ve Rehm, 1997, s. 1261; Snyder, 2002, s. 254). Siralanan bu faktörler incelendiğinde, bunların okul doyumu ile ilişkili olduğu görülmektedir. Diğer bir ifade ile ergenlerin okul doyumları, umut düzeyleri üzerinde etkili olabilen bir faktör olduğu dikkati çekmektedir. Diğger taraftan yaşam doyumu ile umut arasındaki ilişkiyi konu alan çeşitli çalışmalarda ergenlerin umut düzeyleri ile yaşam doyumları arasında pozitif ilişkinin olduğu görülmüştür (Cotoon-Bronk ve vd., 2009, s. 500-510; Merkaš ve Brajša-Žganec, 2011, s. 499-514; Valle, vd., 2006, s. 393-406). Ayrica alan yazında ergenlerin anne-babaya bağlllık ile olumsuz ergen davranışları (Padilla-Walker, Hardy ve Christensen, 2011, s. 853-879), travma sonras1 stres tepkileri ve benlik sayg1s1 (Zhou,Wu ve Zhen, 2018, s. 32-45 ), sosyal destek ve iyi oluş (Yarcheski, Mahon ve Yarcheski, 2001, s. 163-181), mükemmeliyetçilik ve depresyon düzeyleri (Ashby ve vd., 2011, s. 131-139), ergen intihar1 ve depresyon düzeyi (Kwok ve Gu, 2019, s. 635), akademik başarı ve öz saygı (Aydın, Sarı ve Şahin, 2014, s. 20-30) değişkenleri arasındaki ilişkide umut düzeylerinin aracılık etkileri incelemiş ve umudun bu değişkenler arasında pozitif aracllık etkisi olduğu rapor edilmiştir. Ayrıca ergenlerin anne baba tutumları (Jiang, Huebner ve Hills, 2013, s. 349), depresyon düzeyleri (Wong ve Lim, 2009, s. 656), benlik sayg1s1 (Merkas ve Brajša-Žganec, 2011, s. 499-514), öz şefkat düzeyleri (Yang, Zhang ve Kou, 2016, s. 91-95) ile yaşam doyumlan arasındaki ilişkide de umudu arac1 etkiye sahip olduğu da ifade edilmektedir. Ancak alan yazında ortaokul öğrencilerinin okul doyumu ile yaşam doyumları arasındaki ilişkide umudun aracılık etkisini inceleyen bir çalışmaya rastlanmamıştır. Fakat alan yazında öğrencilerin akademik yaşantılarını ve okul temelli yaşantılarının umut düzeyleri üzerinde etkili olduğu ifade edilmekte ve bu konunun araştırlmaya muhtaç bir konu olduğu belirtilmektedir (Gilman, Doley ve Florell, 2006, s. 314-316; Huebner ve McCullough, 2000, s. 331-335).

Alan yazın incelendiği okul doyumunun öğrencilerin yaşam doyumları üzerinde etkili olduğu ifade edilmektedir (Huebner ve Alderman, 1993, s. 77). Ancak öğrencilerin okul doyumları ile araştırmaların ihmal edildiği ve daha fazla çalışmaya ihtiyacın olduğu belirtilmektedir (Jovanović ve Jerković, 2011, s. 211- 
224). Diğer taraftan yaşam doyumu kavramı ve üzerinde etkili olan faktörlerle ilgili araştırmaların daha çok yetişkinler üzerinde yapıldığı, okul çağı çocuk ve ergenler üzerinde araştırmaların sınırlı sayıda olduğu söylenmektedir (Huebner vd., 2005, s. 18). Ancak alan yazında yaşam doyumunun okul çağ1 çocukların ruhsal sağlığı üzerinde etkili olan önemli bir faktör olduğu ve bu nedenle çocuk ve ergenlerin yaşam doyumlarını etkileyen faktörlerin bilinmesinin önemli olduğuna dikkat çekilmektedir (Tian vd., 2013, s.365; Valera vd., 2017, s. 494). Diğer taraftan alan yazında okul çağı çocuklarının umut düzeylerinin yaşam doyumları ve okul doyumları ile arasında pozitif yönde ilişkisinin bulunduğu ancak bu konuyla ilgili araştırmaların da sınırlı olduğu belirtilmektedir (Huebner ve McCullough, 2000, s. 331-335; Snyder, 2002, s. 258). Alanyazın incelendiğinde ortaokul öğrencilerinin okul doyumları ile yaşam doyumları arasındaki ilişkiyi inceleyen sınırlı sayıda araştırma (Huebner ve Alderman, 1993 s. 71-82; Huebner vd., 1998, s. 118134; Karababa vd., 2018, s. 293-315; Lewis vd., 2011, s. 249-262; Valera vd., 2017, s. 487-505) bulunmasına karşın, okul doyumu ve yaşam doyumunu ilişkisinde umudun arac1 rolünü inceleyen araştırmaya rastlanmamıştır. Yine aynı şekilde çocuk ve ergenlerin yaşam doyumları ile başka değişkenler arasındaki ilişkide umudun aracı rolünü inceleyen bazı araştırmalar (Jiang, Huebner ve Hills, 2013, s. 340352; Merkas ve Brajša-Žganec, 2011, s. 499-514; Yang, vd., 2016, s. 91-95) olmasina rağmen umudun okul doyumu ile yaşam doyumu arasındaki aracılık etkisini inceleyen bir çalışmaya ulaşılamamıştır. Yukarıda açıklanan gerekçelere dayanarak bu çalışmada ortaokul öğrencilerinin okul doyumu ile yaşam doyumu arasındaki ilişkide umudun aracı rolünün incelemek amaçlanmıştır. Bu amaç doğrultusunda aşağıdaki sorulara yanıt aranmıştır:

1. Ortaokul öğrencilerinin okul doyumları, yaşam doyumlarını yordamakta mıdır?

2. Ortaokul öğrencilerinin okul doyumları, umut düzeylerini yordamakta mıdır?

3. Ortaokul öğrencilerinin umut düzeyleri, yaşam doyumlarını yordamakta mıdır?

4. Ortaokul öğrencilerinin okul doyumları ile yaşam doyumlanını ilişkisinde umudun aracı rolü bulunmakta midir?

\section{Yöntem}

\section{Araştırmanın Modeli}

Çalışma ilişkisel tarama modelinde bir araştırmadır. İlişkisel tarama modeli, korelasyonel araştırma desenlerinden olup, iki veya daha fazla değişken arasındaki ilişkiyi belirlemek için kullanılan araştırma desenidir (Böke, 2014, s. 164; Büyüköztürk vd., 2017, s. 232). Bu araştırmada ortaokul öğrencilerinin okul doyumlarının yaşam doyumlarını yordamasında, umut düzeylerinin aracı rolünün olup olmadığ1 yapısal eşitlik modellemesi kullanılarak analiz edilmiştir. Bu doğrultuda Şekil-1'de verilen modeller tasarlanmıştır.

Model -1

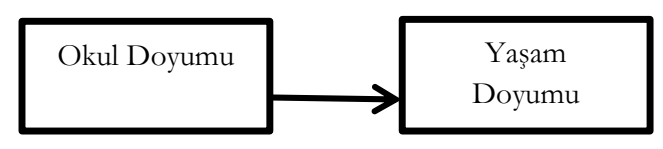

Model-2

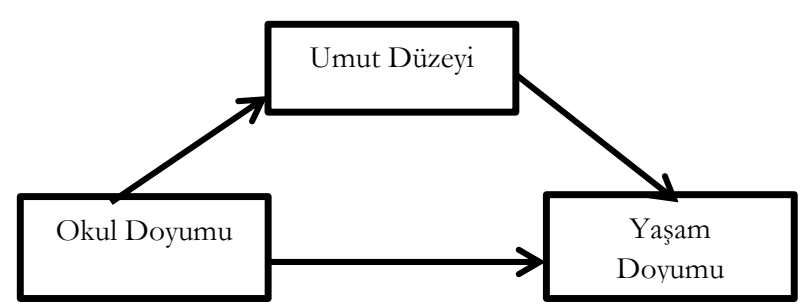

Şekil 1. Araştrma Modelleri

Öncelikli olarak Şekil-1 yer alan Model-1'deki (yol analizi) okul doyumunun yaşam doyumu üzerindeki yordayıcı rolü incelenmiştir. Ardından Model-2'de okul doyumunun, umut aracılllığında yaşam doyumunu yordaması yapısal eşitlik aracıllı̆ı ile incelenmiştir.

\section{Çalışma Grubu}

Çalışmanın örneklem grubunu Tokat ilinde bulunan üç farklı ortaokullardaki 211 öğrenci oluşturmaktadır. Çalışma grubundaki öğrencilerin cinsiyet dağılımlarına bakıldığı zaman 105 'inin kız ve 106'sının erkek öğrenci olduğu görülmüştür. Araştırmaya katıllan öğrencilerin 28'i beşinci sınıf (\%13.3), 53’ü altınc1 sinıf (\%25.1), 66’s1 yedinci sınıf (31.3) ve 64'ü sekizinci sinıfa (\%30.4) devam etmektedir. Örneklem grubundaki öğrencilerin yaşları aralıkları 10 ile 15 arasında değişmektedir $(\bar{x}=12.59$; Ss $=1.27)$. 


\section{Verilerin Toplanmas1}

Araştırmanın yapılabilmesi için öncelikle Ondokuz Mayıs Üniversitesi Sosyal ve Beşeri Bilimleri Bilimler Etik Kurulu'ndan (Karar no: 2019-174) izin alınmıştır. Daha sonra araştırma ile ilgili kurum yetkilileri bilgilendirilmiş ve gerekli uygulama izinleri alındıktan sonra belirlenen ortaokullarda görev yapan rehber öğretmenleri ile iletişime geçilerek, öğrencilerin uygun olduğu saatler tespit edilmiştir. Ardından araştırmaya katılacak öğrencilere sınıf ortamında ölçme araçları uygulanmışır. Bu süreçte toplam 240 öğrenciye ölçme araçları uygulanmıştır. Ölçme araçlarının uygulanması yaklaşık 15-20 dakika sürmüştür. Ölçme araçlarını eksik ve yanlış doldurduğu tespit edilen 29 öğrencinin ölçme araçları değerlendirilmemiştir.

\section{Veri Toplama Araçları}

Kişisel Bilgi Formu. Çalışmaya katılan öğrencilerinden demografik bilgilerinin alınması için kullanilan formdur.

Çocuklar İçin Kapsamlı Okul Doyumu Ölçeği. Randolph, Kangas ve Ruokamo (2009) tarafindan geliştirilen ölçek Telef (2014) tarafindan Türkçeye uyarlanmıştır. Türkçe uyarlama çalışmasında ölçeğin yapısı doğrulayıcı faktör analizi ile incelemiş ve model uyum indekslerinin $\left(x^{2} / s d=3.45\right.$; RMSEA $=.06$, $\mathrm{RMR}=.01, \mathrm{GFI}=.98, \mathrm{NFI}=.99, \mathrm{RFI}=.98, \mathrm{CFI}=.99$ ve $\mathrm{IFI}=0.99)$ iyi uyuma işaret ettiği sonucuna ulaşılmıştır. Ölçeğin Cronbach alfa iç tutarlık katsayısı .89 olarak bulmuştur. Ölçek tek boyut ve altı maddeden oluşmakta ve beşli likert tipinde hazırlanmış bir ölçme aracıdır.

Bu çalışma kapsamında yapılan doğrulayıcı faktör analizinde elde edilen model uyum indekslerine bakıldığında, ölçeğin yapısının mevcut araştırmanın örneklem grubundan elde edilen veriler üzerinde doğrulandığına işaret etmektedir $\left(\chi^{2} / s d=2.33\right.$; RMSEA $=.080, \mathrm{GFI}=.97, \mathrm{NFI}=.97, \mathrm{RFI}=.94, \mathrm{CFI}=.98$ ve IFI= .98). Ayrıca ölçeğin çalışmadaki örneklem grubu üzerinden Cronbach Alfa iç tutarlık katsayıs1 .88 olarak hesaplanmıştır.

Çocuklar İçin Umut Ölçeği. Snyder ve arkadaşlarının (1997) geliştirdiği ölçek Atik ve Kemer (2009) tarafından Türkçeye uyarlanmıştır. Araştırmacılar yapmış oldukları doğrulayıcı faktör analizi elde etmiş olduklar1 model uyum indeksleri $\left(x^{2} / s d=3.73\right.$; RMSEA $=.061$, GFI $=.99$, AGFI $=.97$, CFI $\left.=.98\right)$ sonucunda ölçeğin yapısının Türk kültüründe de geçerli olduğu sonucuna ulaşmışlardır. Ayrıca uyarlama çalışmasında ölçeğin Cronbach alfa iç tutarlık katsayısını .74 olarak hesaplamışladır. Ölçek tek boyut ve altı maddeden oluşmakta ve altılı likert tipinde bir ölçme aracıdır.

Bu çalışma kapsamında yapılan doğrulayıcı faktör analizinde elde edilen model uyum indekslerine bakıldığında, ölçeğin yapısının mevcut araştırmanın örneklem grubundan elde edilen veriler üzerinde doğrulandığına işaret etmektedir $\left(\chi^{2} / s d=1.09 ; \mathrm{RMSEA}=.022, \mathrm{GFI}=.99, \mathrm{NFI}=.97, \mathrm{RFI}=.95, \mathrm{CFI}=.99\right.$ ve IFI= .99). Ayrıca ölçeğin bu çalışmadaki örneklem grubu üzerinden hesaplanan Cronbach Alfa iç tutarlık katsayıs1 82 olarak bulunmuştur.

Çocuklar İçin Yaşam Doyumu Ölçeği. Reichl ve Zumbo (2009) tarafindan geliştirilen ölçek Altay ve Ekşi (2018) tarafindan Türkçeye uyarlanmıştır. Araştırmacılar uyarlama çalışmalarını doğrulayıcı faktör analizi yöntemi ile gerçekleştirmiş ve analiz sonucunda elde etmiş oldukları uyum indeksleri $\left(x^{2} / s d=.80\right.$; RMSEA $=1.00,, \mathrm{GFI}=.99, \mathrm{AGFI}=.99, \mathrm{CFI}=1.00)$, ölçeğin yapısının Türk kültürüne uyum sağladığ1 sonucunu rapor etmişlerdir. Ayrıca uyarlama çalışmasında sırasında ölçeğin Cronbach alfa iç tutarlık katsayısını .79 olarak hesaplamışladır. Ölçek tek boyut beş maddeden oluşmakta ve beşli likert tipinde hazırlanmış bir ölçektir.

Bu çalışma kapsamında yapılan doğrulayıcı faktör analizinde elde edilen model uyum indekslerine bakıldığında, ölçeğin yapısının mevcut araştırmanın örneklem grubundan elde edilen veriler üzerinde doğrulandığına işaret etmektedir $\left(\chi^{2} / s d=1.88 ; \mathrm{RMSEA}=.065, \mathrm{GFI}=.98, \mathrm{NFI}=.98, \mathrm{RFI}=.95, \mathrm{CFI}=.99\right.$ ve IFI= .99). Ayrıca ölçeğin bu çalışmadaki örneklem grubu üzerinden Cronbach Alfa iç tutarlık katsayısı .82 olarak hesaplanmıştır.

\section{Verilerin Analizi}

Araştırmada öncelikli olarak toplanan verilerin betimsel istatistikleri (ortalama, standart sapma, basıklık ve çarpıklık katsayıları) hesaplanmıştır. Diğer açından veri toplama araçlarından elde edilen puanların cinsiyete göre anlamlı olarak farklılaşıp farklılaşmadığını incelemek için bağımsız örneklem $t$ testi, sınıf düzeyine göre anlamlı bir farklılaşma olup olmadığını test etmek için ise tek yönlü varyans (ANOVA) testi kullanılmıştır. Yapısal eşitlik analizine dâhil edilecek değişkenler arasındaki ilişki pearson momentler 
çarpımı korelasyon katsayısı ile incelenmiştir. Bu araştırmada kapsamında toplanan veriler üzerinden çalışmada kullanılan ölçme araçlarının yap1 geçerliğinin doğrulayıcı faktör analizi test edilmiştir. Diğer taraftan değişkenler arasındaki yordayıcı ilişkilerin belirlenmesi için yol analizi, umut değişkenin okul doyumu ve yaşam doyumu arasındaki ilişki üzerindeki aracılığını test etmek için ise yapisal eşitlik modellemesi yöntemi kullanılmıştır. Yapısal eşitlik modellemesinde dolaylı etkilerin anlamlı olup olmadı̆̆ına, bootstrapping yöntemi kullanılarak karar verilmiştir. Bu çalışmada 5000 bootstrap yeniden örnekleme yapılmış ve güven aralıkları belirlenmiştir. Bootstrapping işlemi sonucunda elde edilen dolaylı etkinin anlamlı olduğunun belirlenmesi için hesaplanan güven aralıklarının sıfırı kapsamaması gerektiği ifade edilmektedir (Hayes, 2013, s. 93). Diğer açıdan yapılan doğrulayıcı faktör analizi ve yapısal eşitlik modellerinin sonuçları model uyum indekslerine göre yorumlanmaktadır (Meydan ve Şeşen, 2015, s.37). Bu çalışmadaki doğrulayıcı faktör analizi ve yol analizi sonuçları yorumlanırken $\chi^{2} / s d$, RMSEA, , TLI, IFI, AGFI, RFI, CFI, GFI, NFI değerleri kullanılmaktadır. Model uyum indeksleri değerlendirilirken TLI,CFI ve $\mathrm{NFI} \geq .90$ (Hu ve Bentler, 1999, s.37-41), GFI $\geq .85$ (Jöreskog ve Sörbom, 1988), ve AGFI $\geq .85$ ve RMSEA'nın .080'in altında olması iyi model uyumuna veya .010 'dan küçük olması ise modelin sonuçlarının kabul edilebilir olduğunu göstermektedir (Hu ve Bentler, 1999, s.37; Tabachnick ve Fidell, 2013, s.459). Diğer taraftan x2/sd katsayının iki ve altında olması iyi uyuma, beş kadar olan durumlarda ise kabul edilebilir uyuma işaret etmektedir.(Meydan ve Şeşen, 2015, s.37; Schermelleh-Engel vd., 2003, s. 2374). Verilerin betimsel verileri analiz edilirken SPSS 23, yol analizi ve yapısal eşitlik modelleri test edilirken AMOS 23 istatistik programlarından yararlanılmıştır.

\section{Bulgular}

\section{Ölçeklerinden Elde Edilen Puanlarlara İlişkin Betimleyici İstatistik Bulguları}

Araştırmaya katılan ortaokul öğrencilerine uygulanan okul doyumu, umut ve yaşam doyumu ölçeklerinden elde edilen puanlar ilişkin betimleyici istatistikler Tablo 1'de verilmiştir.

Tablo 1. Ölçeklerinden Elde Edilen Puanlar İliskin Betimleyici İstatistikler

\begin{tabular}{llcccccc}
\hline Değişkenler & $\mathbf{N}$ & $\overline{\mathbf{x}}$ & SS & \multicolumn{2}{c}{ Çarpıklık (skewness) } & \multicolumn{2}{c}{ Basılklk (Kurtosis) } \\
\cline { 5 - 8 } & & & & İstatistik & Std. Hata & İstatistik & Std. Hata \\
\hline Okul Doyumu & 211 & 23.24 & 5.13 & -.895 & .167 & .467 & .333 \\
Umut Düzeyi & 211 & 27.33 & 5.87 & -.675 & .167 & -.210 & .333 \\
Yaşam Doyumu & 211 & 18.98 & 4.54 & -.639 & .167 & -.289 & .333 \\
\hline
\end{tabular}

Çalışmada elde edilen verilerin normal dağılıma sahip olup olmadı̆̆ı incelenmek için basıklık ve çarpıklık değerleri incelenmiş ve alan yazında bu değerlerin +1.5 ile -1.5 arasında bulunması gerektiği önerilmektedir (Tabachnick ve Fidell, 2013, s. 79-81). Tablo 1 incelendiğinde tüm değişkenlerin basıklık ve çarpıklık değerlerinin önerilen referans aralığında olduğu, bu nedenle verilerin normal dağılıma sahip olduğuna ilişkin ölçütün sağlandığı ifade edilebilir.

\section{Cinsiyete Göre Okul Doyumu, Yaşam Doyumu ve Umut Düzeyine İlişkin Bulgular}

Araştırmaya katılan öğrencilerinin okul doyumu, umut düzeyleri ve yaşam doyumlarının cinsiyete göre anlamlı farklılaşıp farklılaşmadığına yanıt aramak için yapılan t testi sonucuna ilişkin bulgular Tablo 2'de verilmiştir.

Tablo 2. Cinsiyete Göre Okul Doyumu, Umut ve Yaşam Doyumu Düzeylerine Göre T-testi Sonuclar

\begin{tabular}{lllccccc}
\hline Değişkenler & Cinsiyet & $\mathbf{N}$ & $\mathbf{x}$ & Ss & Sd & t & p \\
\hline \multirow{2}{*}{ Okul Doyumu } & Erkek & 105 & 24.06 & 4.71 & 209 & 2.34 & $.020^{*}$ \\
& K1z & 106 & 22.43 & 5.40 & .32 & .836 & .40 \\
Umut Düzeyi & Erkek & 105 & 27.68 & 6.10 & 5.63 & .715 \\
Yaşam & K1z & 106 & 27 & 4.53 & .93 \\
Doyumu & Erkek & 105 & 18.95 & 4.41 & & \\
\hline
\end{tabular}

$*_{\mathrm{p}}<.05$

Tablo 2'de ortaokul öğrencilerinin okul doyumu düzeylerinin cinsiyete göre erkek öğrencilerin lehine anlamlı olarak farklılaştı̆̆1 görülmektedir $[\mathrm{t}=2.34 ; \mathrm{p}<.05]$. Diğer bir ifade ile erkek öğrencilerin okul doyumu puan ortalamalarının $(\bar{x}=24.06$; $)$ kız öğrencilerin okul doyumu puan ortalamalarından $(\bar{x}=22.43)$ anlamlı olarak daha yüksek olduğu saptanmıştır. Ancak öğrencilerinin umut ve yaşam doyum puanları arasında cinsiyet değişkenine göre istatistiksel olarak anlamlı bir farklılık olmadığı bulunmuştur ( $\mathrm{p}>.05)$. 


\section{Sınıf Düzeyine Göre Okul Doyumu, Yaşam Doyumu ve Umut Düzeyine İlişkin Bulgular}

Araştırmada ortaokul öğrencilerinin okul doyumlarının, sınıf düzeylerine göre anlamlı olarak farklılaşıp farklılaşmadığına yanıt aramak için yapılan ANOVA testi sonuçları Tablo 3'de sunulmuştur.

Tablo 3. Simf Düzeyine Göre Okul Doyumuna Ilişkin ANOV A Testi Sonuclar

\begin{tabular}{llllllcc}
\hline Değişkenler & Sınıf Düzeyi & $\mathbf{n}$ & $\overline{\boldsymbol{x}}$ & Ss & Sd & $\mathbf{F}$ & $\mathbf{p}$ \\
\hline & 5 & 28 & 24 & 5.50 & 3 & 1.011 & .39 \\
Okul Doyumu Düzeyi & 6 & 53 & 23.77 & 5.11 & 207 & & \\
& 7 & 66 & 23.32 & 5.59 & & & \\
& 8 & 64 & 22.38 & 4.42 & 210 & & \\
\hline
\end{tabular}

(Not: Levene's testi $=1.01, \mathrm{p}=.39 ; \mathrm{p}>.05)$

Tablo 3'deki ANOVA testine göre ortaokul öğrencilerinin okul doyumu düzeyi puanları sınıf düzeyine göre anlamlı olarak farklılaşmadığı görülmektedir ( $\mathrm{p}>$.05).

Araştırmada ortaokul öğrencilerinin umut düzeylerinin, sınıf düzeylerine göre anlamlı olarak farklılaşıp farklılaşmadığına yanıt aramak için yapılan ANOVA testi sonuçları Tablo 4'de sunulmuştur.

Tablo 4. Smrf Düzeyine Göre Umut Düzeyine Illiskein ANOVA Testi Sonuclarn

\begin{tabular}{lllllccccc}
\hline Değişkenler & Sinıf Düzeyi & $\mathbf{n}$ & $\overline{\boldsymbol{x}}$ & Ss & Sd & F & p & $\begin{array}{c}\text { Fark } \\
\text { (Tukey) }\end{array}$ & $\boldsymbol{\eta}^{2}$ \\
\hline & 5 & 28 & 25.83 & 6.87 & 3 & 7.67 & $.000^{*}$ & $5-6$ & \\
\multirow{3}{*}{ Umut Düzeyi } & 6 & 53 & 29.23 & 499 & 207 & & & $6-8$ & .10 \\
& 7 & 66 & 28.72 & 5.60 & & & & $7-8$ & \\
& 8 & 64 & 25.02 & 5.49 & 210 & & & & \\
\hline
\end{tabular}

${ }^{*} \mathrm{p}<.001$ (Not: Levene's testi $\left.=1.19 ; \mathrm{p}=.32 ; \mathrm{p}>.05\right)$

Tablo 4'deki ANOVA testinin sonucuna göre ortaokul öğrencilerinin umut düzeyleri, sinıf düzeyleri anlamlı olarak farklılaşmıştır $\left[\mathrm{F}_{207.3}=7.67 ; \mathrm{p}<.001\right]$. Bu farklılaşmanın hangi gruplar arasından olduğunu incelemek için Post-Hoc testlerinden Tukey gruplar arası karşılaştırma testi yapılmış ve sonuç olarak altınc1 sınıf ortaokul öğrencilerinin umut düzeylerinin $(\bar{x}=29.23)$ beşinci sinıf $(\bar{x}=25.83)$ ve sekizinci sınıf $(\bar{x}$ =25.02) öğrencilerinin umut düzeylerinden anlamlı bir şekilde daha yüksek olduğu saptanmıştır. Benzer şekilde yedinci sınıfa devam eden ortaokul öğrencilerinin umut düzeyleri $(\bar{x}=28.72)$, sekizinci sınıf öğrencilerinin umut düzeylerinden $(\bar{x}=25.02)$ anlamlı bir şekilde daha yüksek olduğu sonucuna ulaşılmıştır.

Araştırmada ortaokul öğrencilerinin yaşam doyumu düzeylerinin, sınıf düzeylerine göre anlamlı olarak farklılaşıp farklılaşmadığına yanıt aramak için yapılan ANOVA testi sonuçları Tablo 5'de sunulmuştur.

Tablo 5. Sinf Düzeyine Göre Yaşam Doyumuna İlişkin ANOV A Testi Sonuclar

\begin{tabular}{|c|c|c|c|c|c|c|c|c|c|}
\hline Değişkenler & Sınıf Düzeyi & $\mathrm{n}$ & $\overline{\boldsymbol{x}}$ & Ss & Sd & $\mathbf{F}$ & $\mathrm{p}$ & $\begin{array}{c}\text { Fark } \\
\text { (Tukey) }\end{array}$ & $\eta 2$ \\
\hline \multirow{5}{*}{ Yaşam Doyumu Düzeyi } & 5 & 28 & 18.86 & 5.42 & 3 & \multirow[t]{5}{*}{5.14} & \multirow[t]{5}{*}{$.002^{*}$} & 6-8 & \multirow{5}{*}{.069} \\
\hline & 6 & 53 & 19.68 & 4.32 & 207 & & & $7-8$ & \\
\hline & 7 & 66 & 20.09 & 4.06 & & & & & \\
\hline & 8 & 64 & 17.30 & 4.07 & 210 & & & & \\
\hline & Toplam & 211 & 18.98 & 4.46 & & & & & \\
\hline
\end{tabular}

$*_{\mathrm{p}}<.01$ (Not: Levene's testi $=.1 .74 ; \mathrm{p}=.16 ; \mathrm{p}>.05$ )

Tablo 5'deki ANOVA testine göre ortaokul öğrencilerinin yaşam doyumları, sınıf düzeylerine göre anlamlı olarak farklılaşmışır $\left[\mathrm{F}_{207.3}=5.14 ; \mathrm{p}<.01\right]$. Bu farklılaşmanın hangi gruplar arasında olduğunun anlaşılması için yapılan Post-Hoc testlerinden Tukey gruplar arası karşılaştırma testi sonucuna göre altıncı sınıf ortaokul öğrencilerinin yaşam doyumu düzeyleri $(\bar{x}=19.68)$ ile yedinci sınıfa ortaokul öğrencilerinin yaşam doyumu düzeyleri ( $\bar{x}=20.09)$, sekizinci sınıf ortaokul öğrencilerinin yaşam doyumu düzeylerinden $(\bar{x}=17.30)$ anlamlı bir şekilde daha yüksek olduğu belirlenmiştir.

\section{Yapısal Eşitlik Modellemesine İlişkin Bulgular}

Analize başlanmadan önce modele ait değişkenler arasındaki ilişkiyi incelemek için yapılan korelasyon analizi sonuçları Tablo 6'da sunulmuştur 
Tablo 6. Yapısal Eșitlike Modellemesine Dâbil Edilecek Olan Değğskenlerin Birbiriyle İliskisi

\begin{tabular}{lccccc}
\hline Değişkenler & $\mathbf{x}$ & $\mathbf{S}$ & $\mathbf{1}$ & $\mathbf{2}$ & $\mathbf{3}$ \\
\hline 1.Okul Doyumu Düzeyi & 23.24 & 5.13 & $.65^{*}$ & 1 & \\
3.Umut Düzeyi & 27.34 & 5.87 & $.59^{*}$ & $.59^{*}$ & 1 \\
4.Yaşam Doyumu Düzeyi & 18.98 & 4.45 & $.49 *$ & $.55^{*}$ & $.68^{*}$ \\
\hline
\end{tabular}

${ }^{*} \mathrm{p}<.01$

Tablo 6 incelendiği zaman regresyon modeline dâhil edilecek bağımlı değişken olan okul doyumu ile umut düzeyi $(\mathrm{r}=.59 ; \mathrm{p}<.01)$ ve yaşam doyumu düzeyi $(\mathrm{r}=.55 ; \mathrm{p}<.01)$ arasından anlamlı pozitif yönde ilişki olduğu gözlenmiştir.

Model-1: Okul Doyumu ile Yaşam Doyumu Arasındaki İlişkisinin İncelenmesine Dair Yol (Path) Analizi Bulgular1

Okul doyumu ile yaşam doyumu ilişkinde umudun aracı rolünün incelenebilmesi için bağımsız değişkenin bağımlı değissken üzerinde anlamlı bir yordayıcı rolünün olması gerektiği ifade edilmektedir (Baron ve Kenny, 1986, s. 1179). Bundan dolayı Model-2'deki aracılık analizin yapılabilmesi için öncelikle Model-1 test edilmiştir. Bununla ilgili sonuçlar Şekil-3'de sunulmuştur.

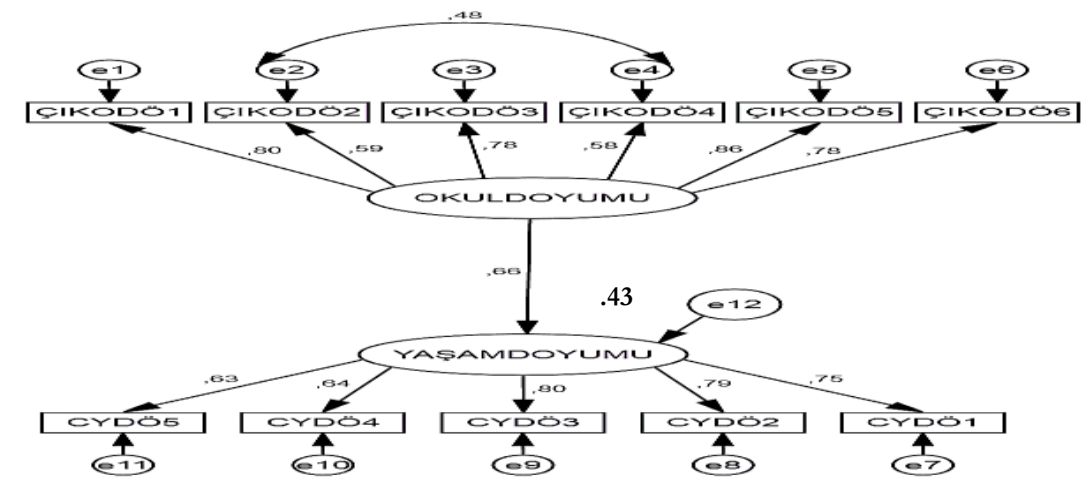

Şekil 2. Model-1'deki Okul Doyumunun Yașam Doyumunu Yordamasina Illiskin Yol Analiæi Diyagramı

Şekil-2'de görüldüğ̈ üzere yol analizinde sadece bir adet modifikasyon yapılmıştır. Yapılan yol analizine ilişkin model uyum indeksleri $(\chi 2 / s d=1.73$; RMSEA $=.059$, GFI $=.94, \mathrm{NFI}=.94, \mathrm{RFI}=.92, \mathrm{CFI}=.97$ ve $\mathrm{IFI}=.97)$ modelin iyi uyum gösterdiğine işaret etmektedir. Yapılan analiz sonucuna ulaşılan yol katsayılanı Tablo 7'de verilmiştir

Tablo 7. Okul Doyumunun Yaşam Doyumunu Yordamasına İliskin Yol Analizi Katsayzlar

\begin{tabular}{ccccccc}
\hline Yordanan & Yordayan & B & $\beta$ (Standart B) &. $\mathbf{t}$ & S.H. & p \\
\hline Yaşam Doyumu $\leftarrow$ Okul Doyumu & .60 & .66 & 7.943 & .076 & $.000^{*}$ \\
\hline
\end{tabular}

${ }^{*} \mathrm{p}<.001$

Tablo 7'de görüleceği üzere okul doyumunun $(\beta=.66, \mathrm{t}=7.94, \mathrm{p}<.001)$ yaşam doyumunun pozitif yönde anlamlı bir yordayıcısı olduğu belirlemiştir. Okul doyumunu yaşam doyumundaki varyansın \%43’nü açıkladığı saptanmıştır $\left(\mathrm{R}^{2}=.43\right)$.

\section{Model-2: Okul Doyumunun ile Yaşam Doyumu Arasındaki İlişkide Umudun Aracılık Rolünün İncelenmesine Dair Bulgular}

Okul doyumunun ile yaşam doyumu ilişkide umudun aracılık rolünü incelemek için Model-2 analiz edilmiştir. $\mathrm{Bu}$ analiz yapılırken aracı değisşken olan umudun bağımsız değişken olan yaşam doyumunu anlamlı bir şekilde yordaması, aynı şekilde okul doyumunun aracı değişken olan umudu anlamlı bir şekilde yordaması gerekmektedir (Baron ve Kenny, 1986, s. 1180). Aynı zamanda aracı değişken olan umudun etkisi kontrol edildiğinde, okul doyumunun yaşam doyumu üzerindeki açıklayıcı etkisini kaybetmesi veya 
azalması beklenmektedir (Hayes, 2013, s. 99). Model-2 ile ilgili yapılan analize ilişkin path diyagramı Şekil3'de, analize ilişkin katsayılar Tablo 8'de sunulmuştur.

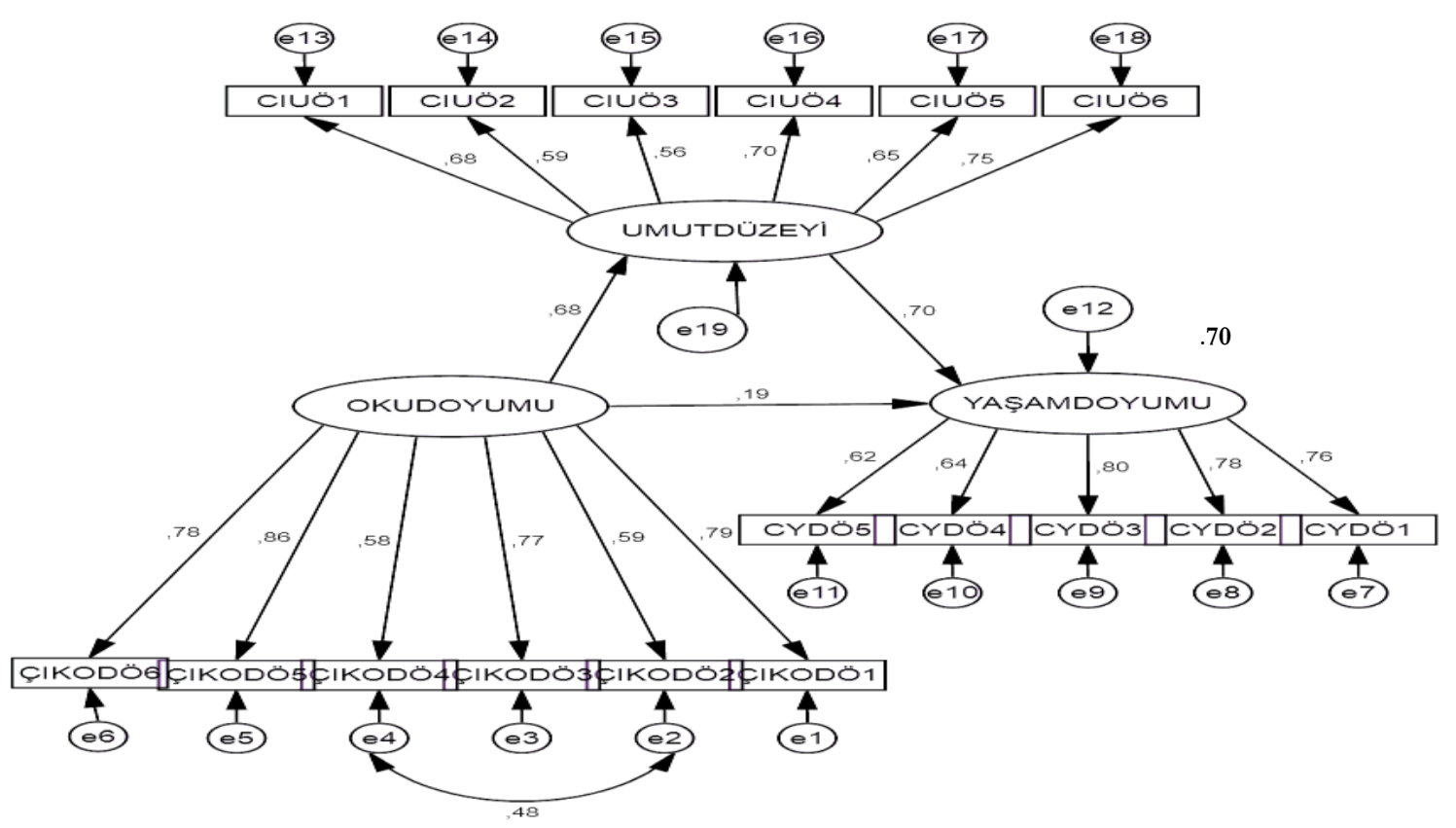

Şekil 3. Model-2’ deki Okul Doyumu ve Yaşam Doyumu Arasında Umudun Aracılık Rolüne İlişkin Path Diyagramı

Şekil-3'deki okul doyumu ve yaşam doyumu arasındaki ilişkide umudun aracıllk rolüne ilişkin yapılan aracılık testine ait model uyum indekslerine bakıldığında $\left(\chi^{2} / s d=1.89\right.$; RMSEA $=.065$, GFI $=.90, \mathrm{NFI}=$ $.94, \mathrm{TLI}=.93, \mathrm{CFI}=.94$ ve $\mathrm{IFI}=.94)$ modelin gerekli uyum iyiliği değerlerini sağladı̆̆1 görülmektedir. Model 2 incelediği zaman okul doyumunun umudu anlamlı ve pozitif bir şekilde yordadığı $(\beta=.68$, $\mathrm{p}<.001)$, yine aynı şekilde umut düzeyinin yaşama doyumunu anlamlı ve pozitif bir şekilde yordadığ1 $(\beta=$ $.70, \mathrm{p}<.001)$ saptanmıştır. Bu sonuçlar aracılık analizindeki değişkenler arasında olması gereken ilişkilerin var olduğu göstermektedir (Baron ve Kenny, 1986, s. 1179). Bu aşamadan sonra Tablo-8'deki aracilık analizine ilişkin bulgular değerlendirilmiştir.

Tablo 8. Okul Doyumu ve Yaşam Doyumu Arasındaki İlişkide Umudun Araculık Rolüne İlişkin Bulgular

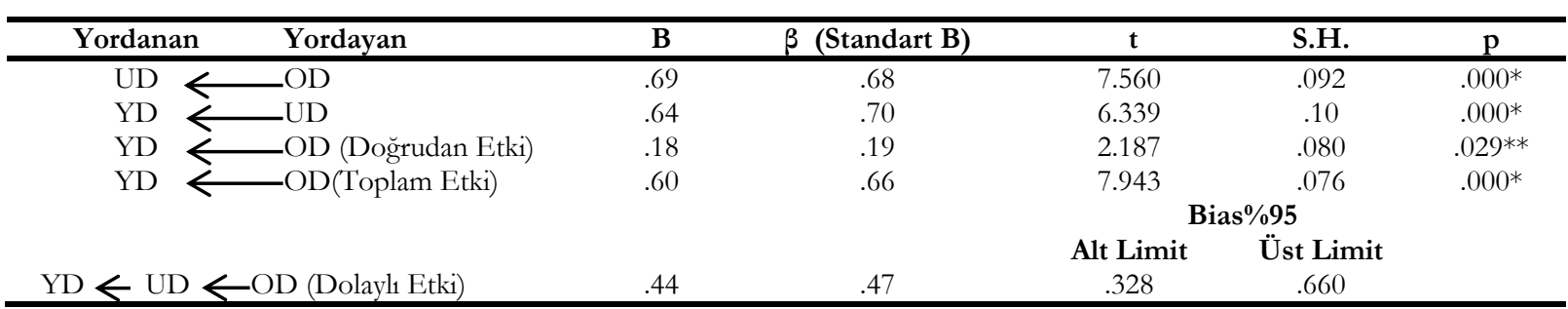

${ }^{*} \mathrm{p}<.001 ;{ }^{* *} \mathrm{p}<.05$ (UD: Umut Düzeyi; OD: Okul Doyumu; YD: Yaşam Doyumu)

Okul doyumu ile yaşam doyumu arasındaki ilişkisinde umudun aracılık rolünün test edildiği yapısal eşitlik modelinde, Tablo 2'de görüldügü gibi okul doyumunun yaşam doyumu üzerindeki yordayıclık düzeyinin (Model1: $\beta=.66, t=7.943, \mathrm{p}<.001$ ), Model-2'de oldukça düştüğü (Model 2: $\beta=.19, t=2.186$ ) fakat $\mathrm{p}<.05$ düzeyinde yordayıcılığının devam ettiği belirlenmiştir. Aynı zamanda Model-2' de umudun yaşama doyumunu anlamlı bir şekilde yordadığı $(\beta=.70, \mathrm{p}<.001)$ görülmüştür. Sonuç olarak okul doyumu ve umut birlikte yaşam doyumuna ait varyansın \% 70'nü açıklamıştır $\left(\mathrm{R}^{2}=.70\right)$.

Model-1 ve Model-2 sonuçları beraber değerlendirildiğinde okul doyumu ile yaşam doyumu arasındaki ilişkide umudun kısmi aracı rolünün olduğu söylenebilir. Çünkü umdun analize dahil edilmesiyle bilirte 
okul doyumunun Model-1'deki Beta değerinin ( $\beta=.66, \mathrm{p}<.001$ ), Model-2'de düştüğü (Model 2: $\beta=.19$, $\mathrm{p}<.05)$ görülmektedir. Ancak okul doyumu yaşamd doyumu üzerindeki yordayıc1lık etkisi hala anlamlıdır. Diğger bir ifade ile okul doyumunun yaşam doyumu üzerinde tek başına doğrudan yordayıcı rolü olmasının yanı sıra, umut aracilığıyla birlikte dolaylı bir etkisinin olduğu da ifade edilebilir. Kısmi aracilık etkisinin anlamlı olup olmadığına karar vermek için bootstrapping işlemi yapılmış ve güven aralıkları incelemiştir. Bootstrapping işlemine göre aracılık $\mathrm{p}<.001$ düzeyinde anlamlı ve $\% 95$ güven aralıklarında alt sınır .328 ve üst sınır .660 olduğu görülmüştür. Bootstrap (özyükleme) katsayılarının alt ve üst limitlerinin sıfirı kapsamadığı için umudun kısmı aracılık etkisinin anlamlı olduğu değerlendirilmiştir (Preacher ve Hayes, 2008, s. 879-891).

\section{Tartışma, Sonuç ve Öneriler}

Yapılan bu araştırmada bir bulgusuna göre erkek öğrencilerin okul doyumlarının kız öğrencilerden yüksek olduğu saptanmıştır. Alan yazında yer alan bir araştırmada erkek öğrencilerin okula doyum düzeylerinin kız öğrencilerin okula bağlllık düzeylerine göre daha yüksek olduğu ifade edilmiştir (Dönmez ve Taylı, 2018, s. 14-15). Ancak yapılan bazı araştırmalarda ise kız öğrencilerin okul doyumlarının erkek öğrencilerin okul doyumlarından daha yüksek olduğunu ifade edilmektedir (Ding ve Hall, 2007, s. 170; Gibbons ve Silva, 2011, s. 329-330; Verkuyten ve Thijs, 2002, s. 223; Y1lmaz, 2017, s. 88). Sonuç olarak alan yazında okul doyumunun cinsiyete göre farklılaşıp farklılaşmadığına ilişkin farklı sonuçlann olduğunu rapor eden çalışmalar bulunmaktadır. Bu sonuçların farklılaşmasında örneklem gruplarının kültürü, ebeveyn tutumları, okul ve eğitim politikalarının etkili olabileceği söylenebilir.

Araştırmanın bir diğer bulgusuna göre ortaokul öğrencilerinin umut düzeyleri ve yaşam doyumlarında cinsiyete göre anlamlı bir farklılık olmadığ bulunmuştur. Huebner (1994, s. 154) araştırmasında ortaokul öğrencilerinin yaşam doyumlarının cinsiyete göre farklılaşmadığını ifade etmiştir. Aynı şekilde Şahin-Baltacı (2018)'in Türkiye ve Amerika'daki ortaokul ögrencilerinin umut düzeyleri ve yaşam doyumlarını kültürel olarak karşılaştığ çalışmasında, her iki ülkedeki öğrencilerin yaşam doyumu ve umut düzeyleri cinsiyete göre anlamlı farklılaşmadığı sonucuna ulaşmıştır. Alan yazında okul doyumu ve umudun cinsiyete göre farklılaşmadığını rapor eden başka çalışmalarda bulunmaktadır (Atik ve Kemer, 2009, s. 384; Esteves, Scoloveno, Mahat, Yarcheski ve Scoloveno, 2013, s. 112; Feldman ve Snyder, 2005, s. 419-420; Özcan ve Kiraz, 2017, s. 105; Snyder vd., 1991 s. 581; Yarcheski ve Mahon, 2016, s. 363). Ancak alan yazinda bulunan bazı çalışmalarda umut ve yaşam doyum düzeylerinin cinsiyete göre anlamlı olarak rapor etmişlerdir (Öztan, 2014, s. 78; Şirin ve Ulaş, 2014, s. 303-304). Yapılan çalışmalardan anlaşılacağı üzere ortaokul öğrencilerinin yaşam doyumu ve umut düzeylerinin cinsiyet değişkene göre farklı sonuçlar raporlayan çalışmalar bulunmaktadır. Ancak yapılan çalışmalarda yaşam doyumu ve umut düzeyinin cinsiyete göre farklılaşmadığını raporlayan çalışmaların daha fazla olduğu görülmektedir. Bu sonuç tüm kültürdeki çocukların cinsiyetlerinin umut ve yaşam doyumu üzerinde anlamlı bir etkisi olmadığı ifade edilebilir. Fakat cinsiyetin yaşam doyumu ve umut üzerindeki etkisi incelenirken çalışan grubun kültürel faktörlerin göz önüne alınmasını daha faydalı olacağı söylenebilir. Çünkü her kültürde çocuk yetiştime biçimleri ve bireylere yüklenenen toplumsal cinsiyet rolleri farklılaştığı için bu durumun öğrencilerin umut ve yaşam doyumu alg1sı üzerinde farklı etkilleri olabileceği düşünülebilir. Bu nedenle bu konuda yeni araştırmaların yapılması bu konun tartışmasına katkı sağlayacağına işaret etmektedir.

Araştırmada ortaokul öğrencilerinin okul doyumlarının sınıf düzeylerine göre anlamlı bir farklılık göstermediği sonucuna ulaşılmıştır. Ancak öğrencilerin sınıf düzeyleri yükseldikçe, öğrencilerin okul doyumu puan ortalamalarında azalmanın meydana geldiği dikkati çekmektedir. Alan yazında yer alan çalışmalar incelendiğinde benzer biçimde sınıf düzeyinin okul doyumunu etkilediğini, sınıf düzeyi düşük olan öğrencilerin okul doyum düzeylerinin daha yüksek olduğunu gösteren araştırma bulgularına ulaşlımıştır (Nickerson ve Nagle, 2004, s. 53-55; Verkuyten ve Thijs, 2002, s. 223). Bir diğer araştırmada ortaokul öğrencilerinin sınıf düzeyinin okul iklimi algısı üzerinde etkili olduğu 6., 7. ve 8. sinıfta öğrenim gören öğrencilerin okul iklimi ölçeği puanlarına bakıldığında, 6 . sınıftaki öğrencilerin puanları en yüksek, 8 . sınıftaki öğrencilerin puanları ise en düşük olduğu rapor edilmiştir (Dönmez ve Taylı, 2018, s. 13). Ortaokul öğrencilerinin sınıf düzeyleri arttıkça okul doyum düzeylerin azalma olması üzerinde, öğrencilerin sınıf düzeylerinin yükselmesi ile beraber akademik sorumluluklarının artması, bu sorumlulukların onlar üzerinde baskı oluşturması ve içinde bulundukları gelişim döneminin (erinlik-ergenlik) getirmiş olduğu psikolojik faktörlerin etkili olabileceği söylenebilir.

Araştırmada ortaokul öğrencilerinin umut düzeylerinin, sınıf düzeyine göre anlamlı olarak farklılaştı̆̆1 sonucuna ulaşılmıştır. Bu sonuca göre altıncı ve yedinci sınıf ortaokul öğrencilerin umut düzeylerinin, 
beşinci ve sekizinci sınıf ortaokul öğrencilerin umut düzeylerinde daha yüksek olduğu saptanmıştır. Bu bulguyu destekler nitelikte olan bir çalışmada ortaokul öğrencilerinin umut düzeylerinin sınıf düzeyine göre anlamlı bir şekilde farklılaştı̆ıını ifade edilmiştir (Yılmaz, 2017, s. 92). Ancak alan yazında öğrencilerin umut düzeylerinin sınıf düzeyine göre anlamlı olarak farklılaşmadığını rapor eden çalışmalar da bulunmaktadır (Kula, 2008 s. 65; Snyder vd., 1991 s. 579, Vidinlioğlu, 2010, s. 65; Yerlikaya, 2014, s. 873). Fakat mevcut çalışmada ortaokul öğrencilerinin umut düzeylerinin sınıf düzeylerine göre oluşan bu farka, öğrencilerin sınıf seviyeleri ile birlikte içinde bulundukları gelişim dönemi etkili olmuş olabilir. Çünkü beşinci sınıf öğrencileri gelişimsel olarak ön ergenlik dönemine girmeye başlamakta ve aynı zamanda okul kademesi değiştirdikleri için okul yaşantılarına dair uyum sorunları yaşama ihtimalleri olduğundan dolayı umut düzeylerinin olumsuz yönde etkilendiği ifade edilebilir. Diğer taraftan sekizinci sınıf öğrencileri ise gelişimsel ergenlik dönemi içerisinde bulunmakta ve aynı zamanda lise giriş sınavlarına hazırlandıkları yoğun bir aşamada yer almaktadırlar. Bundan dolayı sekizinci sınıf öğrencilerinin umut düzeylerindeki azalmanın, ergenlik döneminin getirmiş olduğu gelişimsel zorluklardan ve sınav kaygısından kaynakladığı düşünülebilir.

Araştırmada ortaokul öğrencilerinin yaşam doyumlarının sınıf düzeylerine göre anlamlı olarak farklılaşığı, altıncı ve yedinci sınıfa giden ortaokul öğrencilerinin yaşam doyum düzeyleri, sekizinci sınıfa giden ortaokul öğrencilerinin yaşam doyumlarında daha yüksek olduğu saptanmıştır. Bu bulguyu destekler nitelikte olan Güngör ve Avcı'nın (2017, s. 57) ortaokul öğrencilerinin umut düzeyleri ile yaşam doyumları arasıdaki ilişkiyi inceledikleri çalışmalarında sekizinci sınıf öğrencilerinin yaşam doyumu düzeylerinin diğer sınıf düzeylerindeki öğrencilerden düşük olduğunu sonucuna ulaşmışlardır. Alan yazında yapılan başka bir çalışmada (Yılmaz, 2017, s. 58) ortaokul öğrencilerinin yaşam doyumlarının sınıf düzeyine göre anlamlı olarak farklılaştığı ve sekizinci sınıf öğrencilerinin yaşam doyumların diğer sınıf düzeyindeki öğrencilerden daha düşük olduğu ifade edilmiştir. Lise öğrencileri üzerinde yapılan başka bir çalışmada ise 9.sınıfta öğrenim gören öğrencilerin yaşam memnuniyetinin diğer sınıf düzeylerinden daha yüksek olduğu belirtilmektedir (Doğan ve Çelik, 2014, s. 2124). Mevcut araştırma ve alan yazında sınırlı araştırmaların sonuçları sınıf düzeyi arttıkça yaşam doyum düzeylerinde azalma olduğu göstermektedir. Bu duruma ögrencilerin ortaokulun son yıllarında lise giriş sınavlarına hazırlanıyor olmaları ve içinde bulundukları ergenlik döneminin gelişimsel kaygılarının neden oladuğu ifade edilebilir.

Araştırmada okul doyumu ile yaşam doyumu ilişkide umudun araclık rolünü incelemek için yapısal eşitlik modellemesi kullanılmıştır. Araştırmanın ilk bulgusuna göre ortaokul öğrencilerinin okul doyumlarının, yaşam doyumları üzerinde anlamlı bir yordayıcı rolü bulunmaktadır. Bu sonuca göre ortaokul öğrencilerinin okul doyum düzeyleri arttıkça, yaşam doyumlarının da arttığı ifade edilebilir. Alan yazında bu bulgu destekleyen araştırma sonuçları ve kuramsal bilgiler bulunmaktadır. Öğrencilerin okul doyumu ile yaşam doyumu arasındaki ilişkiyi inceleyen çeşitli araştırmalarda, okul doyumu yüksek olan öğrencilerin yaşam doyum düzeylerinin de yüksek olduğu sonucuna ulaşmışlardır (Huebner ve Alderman, 1993, s. 77; Huebner vd.,1998, s. 129; Karababa vd., 2018, s. 274; Lewis vd., 2011, s. 256; Valera vd., 2017, s. 495). Aynı şekilde alan yazında yapılan başka araştırmalarda öğrencilerin okul doyumları, okul temelli yaşantılardan memnuniyet düzeyleri ile yaşam doyumu arasındaki pozitif ilişkinin olduğu görülmüştür (McCabe vd., 2011, s. 185; Saha vd., 2012, s. 246 ; Tolan ve Larsen, 2014, s. 506). Diğer taraftan alan yazında okul çağı çocukların okul doyumları, yaşam doyumları açısından önemli bir bileşen olarak görülmekte ve öğrencilerin okul temelli yaşantılarından memnuniyet düzeylerinin yaşam doyumlarını büyük oranda etkilediği ifade edilmektedir (Kalayc1 ve Özdemir, 2013, s. 309; Tian vd., 2014, s. 365). Suldo ve arkadaşları (2013) yapmış oldukları araştırmalarında ortaokul öğrencilerinin okul yaşantısından ve okul ikliminden memnuniyetlerinin, yaşam doyumlarını pozitif yönde yordadığı sonucuna ulaşmışlardır. Alan yazında bu şekilde sonuçları rapor eden başka araştırmalar da bulunmaktadır (Natvig, Albrektsen ve Qvarnstrom, 2003, s. 172; Zullig vd., 2011, s. 139). Benzer şekilde alan yazında olumlu eğitsel ortamların öğrencilerin yaşam doyumlarına olumlu yönde katk1 sağladığı ifade edilmektedir (Gilman ve Huebner, 2006, s. 314). Diğer taraftan ortaokul öğrencilerinin okul doyumları ile yaşam doyumları arasındaki ilişskiye dair mevcut araştırma bulgusunun, yaşam doyumunu kavramın teorik yapısıyla da örtüştüğü ifade edilebilir. Çünkü yaşam doyumu, bireylerin aile, sosyal çevre, okul ve arkadaş ilişskileri gibi alanlara dair memnuniyet düzeylerinin toplamından oluşan bir yapıdır (Appleton ve Song, 2008, s. 2333; Diener ve Diener, 1995, s. 659).Öğrencilerin zamanlarının büyük bir kısmını okulda geçirdikleri düşünüldüğ̈ünde, okula yaşantılarına ilişkin bilişsel yargılarının yaşam doyumları üzerinde etkili olması beklenen bir sonuçtur. Bundan dolayı araştırmada elde edilen bu bulgunun kuramsal yapıyla paralellik gösterdiği ve alan yazındaki araştırmaların sonuçları ile benzer olduğu söylenebilir. 
Araştırmada elde edilen bir diğer bulguya göre ortaokul öğrencilerinin okul doyumları, umut düzeylerini anlamlı olarak pozitif bir şekilde yordamamıştır. Diğer bir ifade ile öğrencilerin okul doyumları yükseldikçe umut düzeylerinin de yükseldiği görülmüştür. Alan yazından ortaokul öğrencilerinin okul doyumu ile umut arasındaki ilişkiyi inceleyen araştırmaya rastlanmamışır. Ancak Atik ve Atik (2017, s.164) ortaokul öğrencilerinin akademik öz yeterlikleri ile umut düzeyleri arasındaki ilişkiyi incelenmişler ve sonuç olarak akademik başarının umudu pozitif yönde yordadığı sonucuna ulaşmışlardır. Akademik öz yeterliği yüksek olan öğrencilerin okul doyumlarının da yüksek olacağı düşünüldüğünde mevcut araştırmanın bulgusu Atik ve Atik (2017, s. 164) araştırmasının bulgusu ile örtüştüğü söylenebilir. Alan yazında okul doyumu ile umut düzeyi arasındaki ilişkiyi inceleyen araştırma bulunmamasına karşın, okul yaşantılarının (öğretmen-akran ilişkisi, okul iklimi, akademik başarı) kalitesinin, öğrencilerin umut düzeyi üzerinde pozitif yönde etkili olduğu söylenmektedir (Curr vd., 199, s. 1261; Snyder vd.., 1997, s. 113, Snyder, 2005, s. 7280; Tarhan ve Bacanl, 2016, s. 572). Okul doyumu öğrencilerin okulla ilgili yaşantılanına olumlu ve olumsuz bilişsel değerlendirmelerini içediği görülmektedir. Bu değerlendirmelerin öğrencilerin umut düzeyi üzerinde etkili olabilmesinin, kuramsal açıdan da mümkün olduğu görülmektedir. Snyder'e (2000) göre umut, geleceğe dair olumlu beklentiler geliştirme ve daha sonraki yaşamına dair pozitif amaçlar belirlemeyi içeren bir kavramdır. Ayrıca umut, belirli bir hedefe ulaşma isteği ve çabası olarak da değerlendirilmektedir (Snyder ve Lopez, 2007, s. 329). Snyder (2002, s. 256) umut teorisinde, yaşamdaki olumlu hedef sonuçlarının (elde edilmiş doyum ve başarılar), bireylerin umut düzeylerini arttırdığını ifade etmektedir. Yukarıdaki açıklamalara bakarak öğrencilerin okulla ilgili hedefler belirlemesi ve bu hedefler konusunda çabaları, onların umut düzeylerine olumlu katkılar sağlayacağı ifade edilebilir. Mevcut araştırmadaki okul doyumu ve umut arasındaki ilişkiye dair elde edilen bulgunun hem alan yazındaki araştırmaların sonuçlarıyla hem de kuramsal olarak desteklendiği söylenebilir.

Araştırmanın bir diğer bulgusuna göre ortaokul öğrencilerinin umut düzeyleri yaşam doyumlarını pozitif yönde anlamlı olarak yordamıştır. Bu sonuca bakarak, ortaokul öğrencilerinin umut düzeylerindeki artışın yaşam doyumlarını da arttığı söylenebilir. Alan yazında bu sonuçları destekleyen araştırmalar bulunmaktadır. Örneğin, ortaokul öğrencilerinin umut düzeyi ile yaşam doyumları arasındaki ilişkiyi inceleyen bir araştırmada, öğrencilerinin umut düzeylerinin, yaşam doyumunlarını pozitif olarak yordadığ1 sonucuna ulaşmışlardır (Marques, Lopez ve Micthel, 2013, s. 256). Bir diğer araştırmda (Güngör ve Avc1, 2017, s. 69) ortaokul öğrencilerinin umut düzeylerinin yaşam doyumlarının anlamlı olarak pozitif yönde yordadığ1 görülmüştür. Aynı şekilde yapılan başka bir çalışmada ergenlerin umut düzeyi ile yaşam doyumları arasında pozitif yönde bir ilişkinin olduğunu bulunmuştur (Cotton Bronk vd.,2009, s. 507). Alan yazında umudun yaşam doyumu üzerinde pozitif yordayıcı etkisinin olduğu rapor başka çalışmalarda bulunmaktadır (Park, Peterson ve Seligman, 2004, s. 613; Valle vd., 2006, s. 399). Diğer açıdan umut ile yaşam doyumu kavramlarının teorik alt yapıları incelendiğinde birbirleriyle ilişkili olduğu göze çarpmaktadır. Yaşam doyumu ise bireyin hayatına ilişkin bilişsel değerlendirmeleri olarak ifade edilmektedir (Diener ve Lucas, 1999, s. 215). Umut kavramı bireyi bir amaca bağlanma ve bu amaca ulaşma konusunda çaba harcamaya motive eden bir süreçtir (Snydr, 2002, s. 253-256). Umut düzeyi, bireyin belirlemiş olduğu amaçlardan elde etmiş oldukları olumlu ve olumsuz sonuçlardan da etkilenmektedir (Snydr, 2000, s. 9-15 ). Her iki kavramla ilgili açıklamalar birlikte incelendiğinde umut ile yaşam doyumu arasındaki ilişkiye dair mevcut araştırma bulgusunun beklenen bir sonuç olduğu ifade edilebilir. Çünkü yaşam doyumu bireyin tüm alanlarına ait bilişsel değerlendirmelerinden etkilendiği için bireyin belirlemiss oldukları amaçlardan elde edecekleri olumlu ve olumsuz sonuçlar onların umut düzeylerini, bireylerin umut düzeyleri ise yaşam doyumlarını etkilemesi muhtemeldir. Sonuç olarak umut ile yaşam doyumu arasındaki araştırma bulgusunun alan yazındaki çalışmaların sonuçları ve teorik açıklamalar ile benzer olduğu söylenebilir.

Araştırmada okul doyumu ile yaşam doyumu arasındaki ilişkide umudun aracılık rolünün olup olmadığına incelenmiştir. Araştırmanın bu bulgusuna göre umut, okul doyumu ve yaşam doyumu arasındaki ilişkide kısmi aracıllk rolünün olduğu bulunmuştur. Bu sonuca göre ortaokul öğrencilerinin okul doyumlarının yüksek olması yaşam doyumlarına olumlu katkı sağlamakta ancak umut düzeylerinin yüksek olmasıyla birlikte yaşam doyumlarının daha yüksek olacağı söylenebilir. Alan yazında okul doyumu ile yaşam doyumu arasındaki ilişkide umudun aracılık rolünü inceleyen araştırmaya rastlanmamıştır. Ancak yaşam doyumunun başka değişkenlerle olan ilişkisinde umudun aracı etkisini inceleyen çalışmalar bulunmaktadır. Örneğin, üniversite öğrencileri üzerinde yapmış oldukları araştırmalarında öz şefkat ile yaşam doyumu ilişkisinde umudun pozitif yönde tam aracılık etkisi olduğu sonucuna ulaşmışlardır (Yang, Zhang ve Kou, 2016, s. 91-95). Yine benzer şekilde başka bir araştırmada altı ve sekizinci sınıf öğrencilerinin anne-baba tutumları ile yaşam doyumları arasındaki ilişki umudun aracı rolü incelemiş ve 
sonuç olarak umudun pozitif olarak kısmi aracllık etkisi olduğu belirlenmiştir (Jiang, Huebner ve Hills, 2013, s. 347). Diğer taraftan yapılan başka bir çalışmada (Wong ve Lim, 2009, s. 648-652) ergenlerin depresyon düzeyi ile yaşam doyumu arasındaki umudun pozitif yönde aracılık etkisine sahip olduğu ortaya çıkmıştır. Bu araştırmalarda, ilişkisi incelenen değişkenler arasında umudun anlamlı ve pozitif bir aracıllık etkisine sahip olduğunu belirtilmiştir. Mevcut çalışmada okul doyumu ile yaşam doyumu arasındaki ilişside umudun pozitif yönde kısmi aracilık etkisinin olduğuna dair bulgu umudun aracilık etkisini inceleyen çalısmaların sonuçları ile benzerlik gösterdiği söylenebilir. Diğer taraftan çocuk ve ergenlerin ilgili yapılan bazı çalş̧malarda umudun başka değişkenler arasındaki aracılık rolünü incelendiği görülmektedir. Yapılan bu çalışmalarda ergenlerin travma sonrası stres tepkileri ve benlik saygıları (Zhou,Wu ve Zhen, 2018, s. 3645), sosyal destek ve iyi oluşları (Yarcheski vd., 2001, s. 174), mükemmeliyetçilik ve depresyon düzeyleri (Ashby vd., 2011, s. 135; Kwok ve Gu, 2019, s. 636), akademik başarı ve öz saygıları (Aydın, Sarı ve Şahin, 2014, s. 42) arasındaki ilişkide umudun aracılık etkisini incelemişlerdir. Bu araştırmalarda, ilişkisi incelenen değişkenler arasında umudun anlamlı ve pozitif bir aracılık etkisine sahip olduğunu sonucu rapor etmişledir. Diğer taraftan mevut araştırmadaki okul doyumu ile yaşam doyumu arasında umdun kısmi aracı rolünün olduğu bulgusu kuramsal yapıyla da desteklendiği söylenebilir. Huebner (1994) okul doyumu kavramını açılarken, çocuğun okulun tüm yaşantılardan zevk alabilme ve okulda bulunduğu süre içerisinde kendisini iyi hissetme düzeyi olarak tanımlamış ve okul doyumu yüksek olan öğrencilerin akademik başarılarının yüksek olacağı ve akademik yaşantıları ile daha rahat hedef belirleyeceklerini ifade etmiştir. Snyder (2002, s. 253) ise umut teorisini açiklarken, hedef belirme ve hedef için çabalama bileşenleri önemli olduğunu ve umudun bireyler için yaşam motivasyonu olduğunu belirtmiştir. Snyder 'in (2002, s. 253) umut kavramindaki hedef unsurunun, Huebner'in (1994, s. 154) okul doyumu konseptinin temel kavramlarından birisini oluşturduğu dikkati çekmektedir. Çünkü öğrenciler okul hayatları boyun akademik olarak hedefle belirlemekte ve bu hedefleri için çaba göstermektedirler. Diğer taraftan okul doyumunun çocukların yaşam doyumunu önemli bir bileşeni olduğu bilinmektedir (Diener, 2000, s. 3443). Tüm bu açılklamalar ışı̆̆ında, bireylerin yaşam doyumlarının tüm yaşamındaki tüm alanlarından etkilendiği düşüldüğü zaman, mevcut araştırmada okul doyumu, yaşam doyumu ve umut arasında elde edilen doğrundan ve dolaylı ilişkilerin teorik yapı ile uyum gösterdiği söylenebilir.

$\mathrm{Bu}$ araştırma ortaokul öğrencilerinin okul doyumları ile yaşam doyumları arasındaki ilişkide umudun aracı rolünün incelendiği ilk araştırma olmasına rağmen bazı sınırllıkklar içermektedir. Araştırmanın verileri sadece Orta Karadeniz Bölgesindeki bir ilde yer alan üç farklı ortaokul öğrencisinden elde edilmiştir. Bu durum çalışmanın sonuçlarının genellenebilirliği üzerinde bir sınırlılık oluşturduğu ifade edilebilir. $\mathrm{Bu}$ nedenle daha sonra yapılacak araştırmalarda farklı illerde okuyan ve daha geniş sayıda bir örneklem grubu ile çalışma düzenlenerek daha genellenebilir sonuçlara ulaşılabilir. Bu çalışmada okul doyumu ile yaşam doyumu arasındaki ilişkide umudun aracı rolü incelenmiştir. Bundan sonra yapılacak çalışmalarda bu ilişki arasında aracı rolü olması muhtemel pozitif psikoloji kavramlarından olan iyimserlik, öz şefkat ve öz yeterlik gibi değişkenlerin aracı rolü araştırlabilir.

\section{Etik Beyan}

"Ortaokul Ögrencilerinin Okul Doyumu İle Yaşam Doyumlar Arasindaki İlişki: Umudun Aracı Rolünün İncelenmesi" başlıklı çalışmanın yazım sürecinde bilimsel kurallara, etik ve alıntı kurallarına uyulmuş; toplanan veriler üzerinde herhangi bir tahrifat yapılmamış ve bu çalışma herhangi başka bir akademik yayın ortamına değerlendirme için gönderilmemiştir.

\section{Kaynakça}

Afzal, T. M ve Afzal, M. (2015). Comparison of students' satisfaction and achievement at secondary level in 1slamabad. American Journal of Educational Research, 3(12), 1324-1327.

Altay, D. ve Ekş̧i, H.(2018, Ekim). Cocuklar için yaşam doyum ölçeğig geçerlilike güvenilirlik çalsşması. 5. Uluslararası eğitim bilimleri sempozyumunda sunulan sözlü bildiri. Yıldız Teknik Üniversitesi, İstanbul.

Atik, G. ve Kemer, G. (2009). Çocuklarda umut ölçeği'nin psikometrik özellikleri: Geçerlik ve güvenirlik çalısması. Illkögretim Online, 8(2), 379-390.

Atik, G. ve Atik, Z. E. (2017). Lise öğrencilerinin umut düzeylerinin yordanması: akademik öz-yeterlik ve problem çözmenin rolü. Ë̈itim ve Bilim, 42(190), 157-169.

Aydın, A., Sarıer, Y. ve Uysal, Ş. (2012). Sosyoekonomik ve sosyokültürel değiş̧kenler açısından PISA matematik sonuçlarının karş̧laştırllması, Eğitim ve Bilim, 37, 164, 20-30.

Aydın, B., Sarı, S. V. ve Şahin, M. (2012) Anne-babadan algılanan kabul/ilgi, benlik saygısı ve akademik başarı: Umudun aracı rolü. Cumburiyet Uluslararası Eğitim Dergisi, 3(4), 37-48.

Aydin, B., Sari, S. V. ve Sahin, M. (2014). Parental Acceptance/Involvement, self-esteem and academic achievement: The role of hope as a mediator. Online Submission, 3(4), 37-48. 
Appleton, S. ve Song, L. (2008). Life satisfaction in urban China: Components and determinants. World Development, 36(11), 2325-2340.

Ashby, J. S., Dickinson, W. L., Gnilka, P. B., \& Noble, C. L. (2011). Hope as a mediator and moderator of multidimensional perfectionism and depression in middle school students. Journal of Counseling \& Development, 89(2), 131-139.

Baron, R. M. ve Kenny, D. A. (1986). The moderator-mediator variable distinction in social psychological research: Conceptual, strategic, and statistical considerations. Journal of Personality and Social Psychology, 51, 1173-1182.

Baker, J. A., Dilly, L. J., Aupperlee, J. L. ve Patil, S. A. (2003). The developmental context of school satisfaction: Schools as psychologically healthy environments. School Psychology Quarterly, 18(2), 206-221.

Böke, K. (2014). Sosyal bilimlerde araștırma yöntemleri.(4. Bask1). İstanbul: Alfa Yayınları.

Büyüköztürk, Ş., Çakmak, E. K., Akgün, Ö. E., Karadeniz, Ş. ve Demirel, F. (2017). Bilimsel araştırma yöntemleri. Ankara: Pegem Akademi Yayınları

Chang, L., Chang, C., Stewart, S. M. ve Au, E. (2003). Life satisfaction, self concept, and family relations in Chinese adolescents and children. International Journal of Behavioral Development, 27, 182-189.

Crano, D. W. ve Brewer, M. B. (2002). Principals and methods of social research. New Jersey: Lawrence Erlbaum Associates Publishers.

Carr, A. (2011). Positive Psychology: The science of happiness and buman strength (2nd Edition). New York \& London: Routledge.

Crede J., Wirthwein L., McElvany N. ve Steinmayr R. (2015). Adolescents' academic achievement and life satisfaction: The role of parents' education. Frontiers in Psychology,6, 52.

Curry, L. A., Snyder, C. R., Cook, D. L., Ruby, B. C. ve Rehm, M. (1997). Role of hope in academic and sport achievement. Journal of Personality and Social Psychology, 73, 1257-1267.

K., Hill, P. L., Lapsley, D. K., Talib, T. L. ve Finch, H. (2009). Purpose, hope, and life satisfaction in three age groups. The Journal of Positive Psychology, 4(6), 500-510.

Çengel, M., Totan, T. ve Çöğmen, S. (2017). Okula bağllilk ölçeğinin türkçeye uyarlanması. Abant İz̧et Baysal Üniversitesi Ë̆itim Fakültesi Dergisi, 17 (4), 1820-1837.

Dew, T. ve Huebner, E. S. (1994). Adolescents' perceived quality of life: an exploratory investigation. Journal of School Psychology, 32, 185-199.

Diener, E. (1984). Subjective well-being. Psychological Buletin, 95 (3), 542-575.

Diener, E. ve Diener, M. (1995). Cross-cultural correlates of life satisfaction and selfesteem. Journal of Personality and Social Psychology, 68, 653-663.

Diener, E. ve Lucas, R. E. (1999). 11 personality and subjective well-being. Well-being: Foundations of hedonic psychology. Russell: Sage Foundation.

Diener, E. (2000). Subjective well-being: The science of happiness and a proposal for a national index. American Psychologist, 55 (1), 34-43.

Ding, C. ve Hall, A. (2007). Gender, ethnicity, and grade differences in perceptions of school experiences among adolescents. Studies in Educational Evaluation, 33(2), 159-174.

Doğan, U. ve Çelik, E. (2014). Examining the factors contributing to students' life satisfaction. educational sciences: Theory \& Practice, 14(6), 2121-2128.

Esteves, M., Scoloveno, R., Mahat, G., Yarcheski, A. ve Scoloveno, M. A. (2013). An integrative review of adolescent hope. Journal of Pediatric Nursing 28, 105-113.

Feldman, D. B. ve Snyder, C. R. (2005). Hope and the meaningful life: Theoretical and emprical associations between goal-directed thinking and life meaning. Journal of Social and Clinical Psychology, 24(3), 401-421.

Gibbons, S. ve Silva, O. (2011). School quality, child wellbeing and parents' satisfaction. Economics of Education Review, 30, 312-331.

Gilman, R. ve Huebner, E. S. (2006).Characteristics of adolescents who report very high life satisfaction. Journal of Youth and Adolescence, 35, 311-319.

Goldbeck, L., Schmitz, T.G., Besier, T., Herschbach, P. ve Henrich, G. (2007). Life satisfaction decreases during adolescence. Quality of Life Research, 16, 969-979.

Gökçe, F. (2012). Öğretmen ve velilerin, öğrencilerin okulda geçirdikleri zaman, ders ve dinlenme süreleri ile tatiller ve okul dönemleri konusundaki görüșleri. Kuram ve Uygulamada Ë̆itim Bilimleri, 12(4), 2541-2560.

Güngör, A. ve Avc1, M. (2017). Examining the relationship between hope and life satisfaction among middle school students. Journal of Pedagogical Research, 1(1), 54-63.

Hayes, A. F. (2013). Introduction to mediation, moderation, and conditional process analysis: A regression-based approach. New York: Guilford Press.

Hu, L. T. ve Bentler, P. M. (1999). Cut off criteria for fit indices in covariance structure analysis: Conventional criteria versus new alternatives. Structural Equation Modeling, 6, 1-55.

Huebner, E. S. ve Alderman, G. L. (1993). Convergent and discriminant validation of a children's life satisfaction scale: Its relationship to self- and teacher-reported psychological problems and school functioning. Social Indicators Research, 30, 71-82.

Huebner, E. S. (1994). Preliminary development and validation of a multidimensional life satisfaction scale for children. Psychological Assessment, 6, 149-158. 
Huebner, E. S., Laughlin, J. E., Ash, C. ve Gilman, R. (1998). Further validation of the multidimensional students' life satisfaction scale. Journal of Psychological Assessment, 16, 118-134.

Huebner, E. S., ve McCullough, G. (2000). Correlates of school satisfaction among adolescents. The Journal of Educational Research, 93(5), 331-335.

Huebner, E.S., Valois, R.F., Paxton, R.J. ve Drane, J.W. (2005). Middle school students' perceptions of quality of life. Journal of Happiness Studies, 6, 15-24.

Huebner, E. S., Suldo, S. M., Smith, L. C. ve McKnight, C. G. (2004). Life satisfaction in children and youth: Empirical foundations and implications for school psychologists. Psychology in the Schools, 41, 81-93.

Huebner, E. S. (1991). Initial development of the student's life satisfaction scale. School Psychology International, 12, 31 40.

Jovanović, V. ve Jerković, I. (2011). School satisfaction among secondary school students: Relations with school achievement and mental health indicators. Psibologija, 44(3), 211-224.

Jöreskog, K. G. ve Sörbom, D. (1988). LISREL 7: A guide to the program and applications. Chicago, IL: SPSS Inc.

Jiang, X. U., Huebner, E. S. ve Hills, K. J. (2013). Parent attachment and early adolescents'life satisfaction: The mediatıng effect of hope. Psychology in the Schools, 50(4), 340-352.

Kalayc1, H. ve Özdemir, M. (2013). Lise öğrencilerinin okul yaşamının niteliğine ilişkin algılarının okul bağl1lıkları üzerine etkisi. Gazi Üniversitesi Gąi Eğitim Fakültesi Dergisi, 33(2), 293-315.

Karababa, A. (2018). The relationship between adaptive-maladaptive perfectionism and life satisfaction among secondary school students. Research on Education and Psychology, 2(2), 166-175

Karababa, A., Oral, T. ve Dilmac, B. (2018). The role of perceived social support and value in prediction of school attachment among secondary school students. Hacettepe Üniversitesi Eğitim Fakültesi Dergisi, 33(2), 269-279.

Kemer, G. ve Atik, G. (2005, Eylül). Kirsal kesimde ve kent merkezinde okuyan lise ögrencilerinin umut düzeylerinin aileden algzlanan sosyal destek düzeyine göre karşılaștırlması VIII. Ulusal Psikolojik Danışma ve Rehberlik Kongresi'nde bildiri olarak sunulmuştur. 21-23 Eylül, İstanbul.

Kemer, G. ve Atik, G. (2012). Hope and social support in high school students from urban and rural areas of Ankara, Turkey. Journal of Happiness Studies, 13, 901-911.

King, A. L. D., Huebner, S., Suldo, S. M. ve Valois, R. F. (2006). An ecological view of school satisfaction in adolescence: Linkages between social support and behavior problems. Applied Research in Quality of Life, 1(3-4), 279-295.

Kula, E. (2008). Endüstri meslek lisesi ögrencilerinin umutsuұluk düzeyleri ve saldırganlı durumlar arasindaki iliskinin incelenmesi (Yüksek Lisans Tezi). Sosyal Bilimler Enstitüsü Yeditepe Üniversitesi, İstanbul.

Kwok, S. Y. ve Gu, M. (2019). Childhood neglect and adolescent suicidal ideation: A moderated mediation model of hope and depression. Prevention Science, 20(5), 632-642.

Leung, J. P. ve Leung, K. (1992). Life satisfaction, self-concept, and relationship with parents in adolescence. Journal of Youth and Adolescence, 21(6), 653-665.

Lewis, A. D., Huebner, E. S., Malone, P. S. ve Valois, R. F. (2011). Life satisfaction and student engagement in adolescents. Journal of Youth and Adolescence, 40, 249-262.

Lyubomirsky, S., Sheldon, K. M. ve Schkade, D. (2005). Pursuing happiness: The architecture of sustainable change. Review of general psychology, 9(2), 111-131.

Meydan, C. H. ve Şeşen, H. (2015). Yapısal eşitlik modeli Amos uygulamaları. Ankara: Detay Yayıncilık.

Merkaš, M. ve Brajša-Žganec, A. (2011). Children with different levels of hope: are there differences in their selfesteem, life satisfaction, social support, and family cohesion? Child Indicators Research, 4(3), 499-514.

Milli Eğitim Bakanlı̆̆1 (2013). PISA 2012 Ulusal Ön Raporu, http://pisa.meb.gov.tr/wpcontent/uploads/2013/12/pisa2012-ulusal-on-raporu.pdf.

Marques, S. C., Lopez, S. J. ve Mitchell, J. (2013). The role of hope, spirituality and religious practice in adolescents' life satisfaction: Longitudinal findings. Journal of Happiness Studies, 14(1), 251-261.

McCabe, K., Bray, M. A., Kehle, T. J., Theodore, L. A. ve Gelbar, N. W. (2011). Promoting happiness and life satisfaction in school children. Canadian Journal of School Psychology, 26(3), 177-192.

McKnight, C. G., Huebner, E. S. ve Suldo, S. (2002). Relationships among stressful life events, temperament, problem behavior, and global life satisfaction in adolescents. Psychology in the Schools, 39(6), 677-687.

Myers, D. G. ve Diener, E. (1995). Who is happy?. Psychological science, 6(1), 10-19.

Nickerson, A. B. ve Nagle, R. J. (2004). The influence of parent and peer attachments on life satisfaction in middle childhood and early adolescence. Social Indicators Research, 66, 35-60.

Natvig, G. K., Albrektsen, G. ve Qvarnstrom, U. (2003). Associations between psychosocial factors and happiness among school adolescents. International Journal of Nursing Practice, 9, 166-175.

Öztan, S. (2014). Ortaokul 6. 7. 8. sinı ögrencilerinin okul tükenmişliklerinin yaşam doyumlar ve benlik. kurgusu algılar aģısından incelenmesi (Yüksek Lisans Tezi). Arel Üniversitesi Sosyal Bilimler Enstitüsü, İstanbul.

Ozcan, B. ve Kiraz, A. (2017). Kıbrıs'ın kuzeyinde yaşayan ergenlerin yaşam memnuniyetleri [Life satisfaction of adolescents living in Northern Cyprus]. Tarih Kültür ve Sanat Araştırmalar Dergisi, 6(3), 88-106.

Park, N., Peterson, C. ve Seligman, M. E. (2004). Strengths of character and well-being. Journal of Social and Clinical Psychology, 23(5), 603-619.

Padilla-Walker, L. M., Hardy, S. A. ve Christensen, K. J. (2011). Adolescent hope as a mediator between parent-child connectedness and adolescent outcomes. The Journal of Early Adolescence, 31(6), 853-879. 
Saha, R., Huebner, E. S., Hills, K. J., Malone, P. S. ve Valois, R. F. (2014). Social coping and life satisfaction in adolescents. Social Indicators Research, 115(1), 241-252.

Preacher, K. J. ve Hayes, A. F. (2008). Asymptotic and resampling strategies for assessing and comparing indirect effects in multiple mediator models. Behavior Research Methods, 40(3), 879-891.

Schermelleh-Engel, K., Moosbrugger, H. ve Muller, H. (2003). Evaluating the fit of structural equation models: Tests of significance and descriptive goodness-of-fit measures. Method of Psychological Research, 8(2), 23-74.

Saminathen, M. G., Låftman, S. B. ve Modin, B. (2019). School Choice at a Cost? Academic Achievement, School Satisfaction and Psychological Complaints among Students in Disadvantaged Areas of Stockholm. International Journal of Environmental Research Public Health, 16 (11), 1-18.

Snyder, C. R., Harris, C., Anderson, J. R., Holleran, S. A., Irving, L. M., Sigmon, S. T. et al.(1991). The will and the ways: Development and validation of an individual-differences measure of hope. Journal of Personality and Social Psychology, 60, 570-585.

Snyder, C. R., Cheavens, J. ve Sympson, S. C. (1997). Hope: an individual motive for social commerce. Group Dynamics: Theory, Research and Practice, 1(2), 107-118.

Snyder, C. R. (2000). Hypothesis: there is hope. In C.R. Snyder (Ed.), Handbook of hope theory, measures and applications (3-18). San Diego: Academic Press.

Snyder, C. R. (2002). Hope theory: rainbows in the mind. Psychological Inquiry, 13(4), 249-275.

Snyder, C. R., Shorey, H. S., Cheavens, J., Mann Pulvers, K., Adams, V. H. ve Wiklund, C. (2002). Hope and academic success in college. Journal of Educational Psychology, 94(4), 820-826.

Snyder, C. R. (2005). Teaching: The lessons of hope. Journal of Social and Clinical Psychology, 24(1), 72-84.

Snyder, C. R. ve Lopez, S. J. (2007). Positive Psychology: the scientific and practical explorations of human strengths. US: Sage Publications, Inc.

Suldo, S. M. ve Huebner, E. S. (2004). Does life satisfaction moderate the effects of stressful life events on psychopathological behavior during adolescence? School Psychology Quarterly, 19, 93-105.

Suldo, S. M., Riley, K. N. ve Shaffer, E. J. (2006). Academic correlates of children and adolescents' life satisfaction. School Psychology International, 27(5), 567-582.

Suldo, S. M. ve Shaffer, E. J. (2008). Looking beyond psychopathology: The dual-factor model of mental health in youth. School Psychology Review, 37, 52- 68.

Suldo, S. M., Thalji-Raitano, A., Hasemeyer, M., Gelley, C. D. ve Hoy, B. (2013). Understanding middle school students life satisfaction: Does school climate matter? Applied Research in Quality of Life, 8(2), 169-182.

Şirin, A. ve Ulaş, E. (2015). Ortaokul öğrencilerinin öznel iyi oluş düzeyleri ile karakter eğitimi uygulamaları arasındaki ilişkinin incelenmesi. Değerler Ë̆itimi Dergisi, 13(30), 279-307.

Tabachnick, B. G. ve Fidell, L. S. (2013). Using multivariate statistics (6 $6^{\text {th }}$ Edition). Boston: Pearson

Tarhan, S., Bacanli, H., Dombayc1, M. A. ve Demir, M. (2011). Quadruple thinking: hopeful thinking. Procedia Social and Behavioral Sciences, 12, 568-576.

Telef, B. B. (2014). Çocuklar için kapsamlı okul doyumu ölçeğinin Türkçeye uyarlama çalışması. Eğitimde Kuram ve Uygulama, 10(2), 478-490.

Tian, L., Chen, H. ve Huebner, E. S. (2014). The longitudinal relationships between basic psychological needs satisfaction at school and school-related subjective well-being in adolescents. Social Indicators Research, 119(1), 353-372.

Tetley, J. (2010). An investigation of self-authorship, hope, and meaning in life among second-year college students (Doctoral Dissertation). The George Washington University, Washington

Tolan, P. H. ve Larsen, R. (2014). Trajectories of life satisfaction during middle school: Relations to developmentalecological Microsystems and student functioning. Journal of Research on Adolescence, 24, 497-511.

Ullman, C. ve Tatar, M. (2001). Psychological adjustment among Israeli adolescents immigrants: A report on life satisfaction, self concept, and self-esteem. Journal of Youth and Adolescence, 30, 449-463.

Varela, J. J., Zimmerman, M. A., Ryan, A. M., Stoddard, S. A., Heinze, J. E. ve Alfaro, J. (2018). Life satisfaction, school satisfaction, and school violence: A mediation analysis for Chilean adolescent victims and perpetrators. Child Indicators Research, 11(2), 487-505.

Valle, M. F., Huebner, E. S. ve Suldo, S. M. (2006). An analysis of hope as a psychological strength. Journal of School Psychology, 44(5), 393-406.

Vidinlioğlu, S. Ö. (2010). Ortä̈gretim ögrencilerinin benlik algist ve umutsuұluk düzeyleri arasındaki ilişki (Yüksek Lisans Tezi). Sakarya Üniversitesi Sosyla Bilimler Enstitüsü, Sakarya.

Verkuyten, M. ve Thijs, J. (2002). School satisfaction of elementary school children: The role of performance, peer relations, ethnicity, and gender. Social Indicators Research, 59, 203-228.

Yang, Y., Zhang, M. ve Kou, Y. (2016). Self-compassion and life satisfaction: The mediating role of hope. Personality and Individual Differences, 98, 91-95.

Yerlikaya, I. (2014). Devlet ve özel ortaokul öğrencilerinin umutsuzluk düzeyinin belirlenmesi ve çeşitli değişkenlerle ilişkisinin incelenmesi. Electronic Turkish Studies, 9(8), 865-877.

Yıldız, M. A. ve Kutlu, M. (2015). Erinlerde okula bağlanmanın yordayicisi olarak sosyal kayg1 ve depresif belirtilerin incelenmesi. Mustafa Kemal Üniversitesi Sosyal Bilimler Enstitüsü Dergisi, 12(31), 332-345. 
Y1lmaz, E. (2017). Ortaokul ögrencilerinin akademik başarlarmm yordanmasinda umut ve yaşam doyumlarmmn incelenmesi (Yüksek Lisans Tezi). Eğitim Bilimleri Enstitüsü Marmara Üniversitesi, İstanbul.

Zullig, K. J., Huebner, E. S. ve Patton, J. M. (2011). Relationships among school climate domains and school satisfaction. Psychology in the Schools, 48(2), 133-145.

Zournazi, M. (2004). Umut değişim için yeni felsefeler (Çev: U. Abac1). İstanbul: Literatür Yayınc1lık.

Zhou, X., Wu, X. ve Zhen, R. (2018). Self-esteem and hope mediate the relations between social support and posttraumatic stress disorder and growth in adolescents following the Ya'an earthquake. Anxiety, Stress, \& Coping, 31(1), 32-45.

Yarcheski, A., Mahon, N. E. ve Yarcheski, T. J. (2001). Social support and well-being in early adolescents: The role of mediating variables. Clinical Nursing Research, 10(2), 163-181.

Yarcheski, A. ve Mahon, N. E. (2016). Meta-analyses of predictors of hope in adolescents. Western Journal of Nursing Research, 38(3), 345-368.

Wong, S. S. ve Lim, T. (2009). Hope versus optimism in Singaporean adolescents: Contributions to depression and life satisfaction. Personality and Individual Differences, 46(5-6), 648-652.

\section{EXTENDED ABSTRACT}

Schools are educational environments that offer students' cognitive, affective and behavioral educational and teaching experiences (Çengel, Totan, \& Çöğmen, 2017, p. 182; Yıldız, \& Kutlu, 2015, p. 355). The knowledge and skills acquired by the individual under the umbrella of the school, and the quality of the relationship established with friends and teachers play an important role in all the child's living spaces (Karababa, Oral, \& Dilmaç, 2018, p. 168). In this process, the concept of school satisfaction, which is an influential factor on the quality of all these relationships, appears (King et al., 2006, p.182). School satisfaction is defined as the level of enjoyment of all the experiences of the school, which is the institution where the child is located, and feeling good during the time he / she is in school (Huebner, 1994, p. 151). In addition, school satisfaction is the cognitive and emotional assessment of students' experiences at school (Huebner, \& McCullough, 2000, p. 331-335; Baker, et al., 2003, p. 203; Verkuyten \& Thijs, 2002, p. 203). On the other hand, school satisfaction is an important concept that constitutes an important dimension of general life satisfaction (Tian et al., 2014, p. 360).

In this study, it is aimed to examine the mediating role of hope in the relationship between secondary school students' school satisfaction and life satisfaction. In addition, students' life satisfaction, hope and school satisfaction levels were examined in terms of gender and grade levels.

In this study, it is a research on relational screening model in terms of the predictive role of hope, life satisfaction and academic achievement levels of secondary school students on school satisfaction. The data of the study consisted of 105 female and 106 male students from different secondary schools in 2018-2019. Of the students participating in the study, 28 were in fifth grade (13.3\%), 53 were in sixth grade (25.1\%), 66 were in seventh grade (31.3) and 64 were in eighth grade $(30.4 \%)$. The age range of the participating students ranged from 10 to 15 , with an average age of 12.59 and $\mathrm{Ss}=1.27$. Comprehensive School Satisfaction Scale for Children, Life Satisfaction Scale for Children and Life Satisfaction Scale for Children were used to collect the data of the study. . Independent sample t-test, one way variance analysis, structural equation modeling and confirmatory factor analysis were used in the study.

It is seen that the school satisfaction levels of secondary school students differ significantly in favor of male students according to gender $(\mathrm{p}<.05)$. In other words, it was found that the mean score of school satisfaction of male students $(\bar{x}=24.06 ; t=2.34)$ was higher than that of female students $(\bar{x}=22.43)$. School satisfaction levels of secondary school students did not differ significantly according to grade level. It is seen that there is a statistically significant difference between hope levels and grade levels of secondary school students $\left(\mathrm{F}_{207.3}=7.67 ; \mathrm{p}<.001\right)$. According to this result, the hopes of sixth grade students were significantly higher $(\bar{x}=29.23)$ than the hopes of fifth grade $(\bar{x}=25.83)$ and eighth grade $(\bar{x}$ $=25.02)$ students. It is seen that there is a statistically significant difference between life satisfaction levels and grade levels of secondary school students $\left(\mathrm{F}_{207.3}=5.14 ; \mathrm{p}<.01\right)$. In the structural equation modeling, it was determined that hope has a partial mediating role in the relationship between secondary school students' school satisfaction and life satisfaction. In order to decide whether the partial mediation effect is meaningful, bootstrapping was performed and the confidence intervals were examined. Lower bound .328 and upper limit was .660 at 95\% confidence intervals in the bootstrapping process $(\mathrm{p}<.001)$. Since the lower and upper limits of the bootstrap coefficients do not include zero, part of the hope is considered to be significant in mediating effect (Preacher \& Hayes, 2008). 
As a result, it was observed that the school satisfaction and hope levels of middle school students were factors affecting their life satisfaction. In addition, it was concluded that the high level of hope of the students together with their school satisfaction contributed more to their life satisfaction. Based on the results, supportive practices aimed at increasing the students' life satisfaction, school satisfactrion and hope levels and developing positive emotions can also contribute to the awareness of parents on of the students. In addition, teachers and school administrators can draw attention to the negative effects of focusing on students' just academic achievements and start studies to increase students' level of school satisfaction, life satisfaction and hope.

Although this study is the first study to examine the role of hope in the relationship between secondary school students' school satisfaction and life satisfaction, it contains some limitations. Research data were obtained only from a junior high school students involved in three different provinces in Turkey. This situation can be stated to constitute a limitation on the generalizability of the results of the study. For this reason, more generalizable results can be obtained by organizing studies with a larger number of sample groups studying in different provinces. In this study, the mediating role of hope in the relationship between school satisfaction and life satisfaction was examined. In future studies, the mediating role of variables such as optimism, self-compassion and self-efficacy, which are among the positive psychology concepts likely to have an intermediary role in the relationship between school satisfaction and life satisfaction, can be investigated. 